\title{
Synthesis and Structure-Activity Relationships in a Series of Ethenesulfonamide Derivatives, a Novel Class of Endothelin Receptor Antagonists
}

\author{
Hironori Harada, ${ }^{*}$ Jun-ichi Kazami, Susumu Watanuki, Ryuji Tsuzuki, ${ }^{1)}$ Katsumi Sudoh, \\ Akira Fujimori, Tatsuhiro Tokunaga, Akihiro TAnAKA, ${ }^{2)}$ Shin-ichi Tsukamoto, and Isao Yanagisawa \\ Institute for Drug Discovery Research, Yamanouchi Pharmaceutical Co., Ltd., 21 Miyukigaoka, Tsukuba, Ibaraki \\ 305-8585, Japan. Received August 1, 2001; accepted September 21, 2001
}

\begin{abstract}
In the previous paper, we described a series of the 2-arylethenesulfonamide derivatives, a novel class of ET $_{A^{-}}$ selective endothelin (ET) receptor antagonists, including the compounds 1a, b. Compound 1a showed excellent oral antagonistic activities and pharmacokinetic profiles, and the monopotassium salt of 1 (YM-598 monopotassium) is in clinical trials. In this paper, we wish to report the investigation of the further details of structure-activity relationships (SARs) of the 2-phenylethenesulfonamide region in 1a. It was found that methyl substitutions at the 2-, 4- and 6-positions of the phenyl group in 1a led to the discovery of the $\mathbf{E T}_{\mathrm{A}} / \mathbf{E T _ { B }}$ mixed antagonist (6s) with an $\mathrm{IC}_{50}$ of $2.2 \mathrm{nM}$ for the $\mathrm{ET}_{\mathrm{A}}$ receptor. We also found that introduction of an ethyl group to the 1-position of the ethenyl group in 1a gave the $\mathrm{ET}_{\mathrm{A}}$ selective antagonist (6u) with an oral endothelin antagonistic activity in rats.
\end{abstract}

Key words endothelin antagonist; endothelin-A/endothelin-B mixed antagonist; ethenesulfonamide; endothelin-A selective antagonist

Endothelin (ET), isolated from the conditioned medium of cultured porcine vascular endothelial cells in 1988, is a highly potent vasoconstrictive 21 -amino acid peptide. ${ }^{3)}$ There are three isoforms (ET-1, ET-2, ET-3). ET-1 is the predominant component of the three ET-isopeptides and is derived from precursor big ET-1. ${ }^{4)}$ ET-1 has been believed to be implicated in the pathogenesis of various diseases, largely because of its ability to constrict vascular and nonvascular smooth muscle. ${ }^{5)}$

Two subtypes of receptors for ETs , termed the $\mathrm{ET}_{\mathrm{A}}$ receptor and $\mathrm{ET}_{\mathrm{B}}$ receptor, have been cloned and stably expressed in mammals. $\mathrm{ET}_{\mathrm{A}}$ receptor appears to exhibit affinity for ET1 and ET-2 over ET-3, whereas the $\mathrm{ET}_{\mathrm{B}}$ receptor has nearly equipotent affinity for these three ETs. ${ }^{6}$ )

$\mathrm{A}$ number of $\mathrm{ET}_{\mathrm{A}}$-selective and $\mathrm{ET}_{\mathrm{A}} / \mathrm{ET}_{\mathrm{B}}$ mixed antagonists have been reported for a decade, ${ }^{7)}$ and some of these $\mathrm{ET}$ antagonists are currently in clinical trials.

In the previous paper, ${ }^{8)}$ we described a series of the 2arylethenesulfonamide derivatives, a novel class of $\mathrm{ET}_{\mathrm{A}}$-selective ET receptor antagonists, including the compounds (1a,b) (Fig. 1). Among these, the potassium salt of 1a (YM598 monopotassium) is in clinical trials. Compound 1a showed an $\mathrm{IC}_{50}$ value of $3.1 \mathrm{nM}$ for the $\mathrm{ET}_{\mathrm{A}}$ receptor and $1200 \mathrm{~nm}$ for the $\mathrm{ET}_{\mathrm{B}}$ receptor $\left(\mathrm{ET}_{\mathrm{B}} / \mathrm{ET}_{\mathrm{A}}\right.$ ratio=390). In the in vivo study, it showed a potent oral inhibitory activity of pressor response to big ET-1-treated rats and excellent pharmacokinetic profiles in rats and dogs. In this paper, we wish to report the investigation of the further details of the structureactivity relationships (SARs) of the 2-phenylethenesulfonamide region in $\mathbf{1 a}$.

In the previous study, ${ }^{8 b)}$ replacement of the phenyl group of the 2-phenylethenesulfonmamide moiety in compound 1a with another aryl or heteroaryl groups was explored. This exercise revealed that these modifications were well tolerated in the $\mathrm{ET}_{\mathrm{A}}$ binding affinity and remarkably led to various $\mathrm{ET}_{\mathrm{B}} / \mathrm{ET}_{\mathrm{A}}$ ratios in the $50-820$ range. Intrigued by these observations, we became interested in the effect of the further modification of the phenyl group in the phenylethenesulfonamide moiety of 1a on both $\mathrm{ET}_{\mathrm{A}}$ and $\mathrm{ET}_{\mathrm{B}}$ binding affinities and the $\mathrm{ET}_{\mathrm{A}} / \mathrm{ET}_{\mathrm{B}}$ ratio. We also investigated modification of the ethenyl group in the phenylethenesulfonamide moiety.

\section{Chemistry}

Charts 1 and 2 show the syntheses of alkenesulfonamide derivatives.

The starting compound (3) was prepared according to the method reported by Burri and his coworkers. ${ }^{9)}$ Nucleophilic substitution of the pyrimidine derivative 3 with $(E)$-alkenesulfonamide (4) resulted in the chloropyrimidine $(\mathbf{5 a}-\mathbf{j}, \mathbf{m}-$ $\mathbf{x})$. The chloropyrimidine $\mathbf{5}$ was treated with sodium methoxide in $N, N$-dimethylformamide (DMF) or methanol to give the methoxy analogues $(\mathbf{6 a}, \mathbf{c}-\mathbf{j}, \mathbf{m}-\mathbf{x})$. Compound $\mathbf{3}$ was also treated with the methyl ester (4k) to give a mixture of the benzoic acid analogue (5l) and the methyl ester (5k). This mixture was treated with concentrated sulfuric acid in methanol to give $\mathbf{5 k}$ as a sole product. Treatment of $\mathbf{5 k}$ with sodium methoxide in methanol gave the benzoic acid analogue (61). Under these reaction conditions, in situ hydrolysis of the esters was observed. Esterification of $\mathbf{6} 1$ gave the methyl ester $\mathbf{6 k}$. The chloropyrimidine $\mathbf{5 b}$ was treated with sodium and ethyleneglycol to afford the hydroxyethoxy derivative $\mathbf{6 b}$. The $(E)$ form of all screened compounds $\mathbf{6}$ was

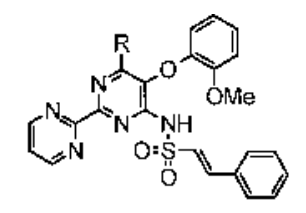

$$
\begin{aligned}
& \text { 1a: } \mathrm{R}=\mathrm{MeO} \\
& \text { YhI598 monopotassium :potassium salt of } 1 \mathrm{a} \\
& \text { 1b: R }=\mathrm{HOCH}_{2} \mathrm{CH}_{2} \mathrm{O}
\end{aligned}
$$

Fig. 1 


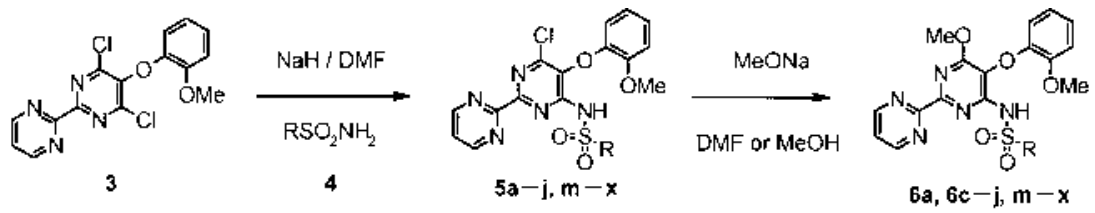

$4 a-j, m-x: R_{2} O_{2} \mathrm{NH}_{2}=\quad \overbrace{\mathrm{R}^{+}}^{\mathrm{R}} \mathrm{SO}_{2} \mathrm{NH}_{2}$
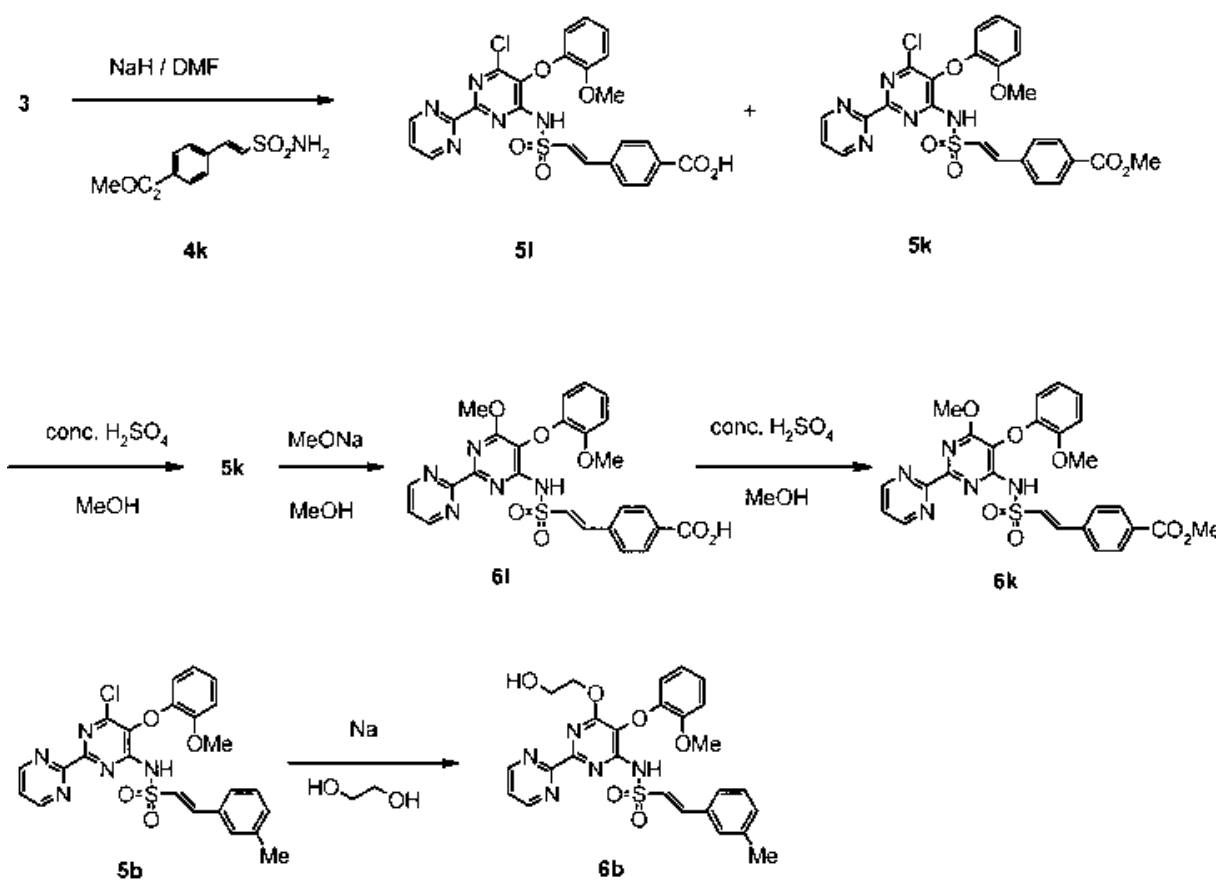

Ar $=$ aryl, BMF = N,N-dimethylformamide

Chart 1

confirmed by the coupling constant between the vinyl protons $(J>14 \mathrm{~Hz})$ in the ${ }^{1} \mathrm{H}-\mathrm{NMR}$ spectrum except for $\mathbf{6 t}-\mathbf{x}$.

In Chart 2, an outline of the synthesis of the key intermediates $\mathbf{4}$ is given.

A palladium-catalyzed Heck reaction between ethenesulfonamide (7) and arylbromide afforded the (E)-2-phenylethenesulfonamide derivatives $(\mathbf{4 c}, \mathbf{d}, \mathbf{f}-\mathbf{i}, \mathbf{m}-\mathbf{s})$ (method A). ${ }^{10)}$ Under the same condition, methyl 4-bromobenzoate was reacted with 7 to afford the benzoic acid analogue (4I). Esterification of $\mathbf{4 l}$ gave the methyl ester $\mathbf{4 k}$. (method B)

Other $(E)$-2-arylethenesulfonamide derivatives $(\mathbf{4 a}, \mathbf{b}, \mathbf{e}, \mathbf{j}$, $\mathbf{t}-\mathbf{x})$ have been synthesized via the route shown in method C. ${ }^{11)}$ The styrene derivatives (8) were treated with sulfuryl chloride and followed by the treatment with aqueous ammonia to give the ethenesulfonamide derivatives $4 \mathbf{4 a}, \mathbf{b}, \mathbf{e}, \mathbf{j}$. The $(E)$-form of the disubstituted $(E)$-2-phenylethenesulfonamide derivatives $\mathbf{4 a}-\mathbf{k}, \mathbf{m}-\mathbf{s}$ was confirmed by the coupling constant between the vinyl protons $(J>14 \mathrm{~Hz})$ in the ${ }^{1} \mathrm{H}-\mathrm{NMR}$ spectrum. The trisubstituted $(E)$-2-phenylethenesulfonamide derivatives $(\mathbf{4 t}-\mathbf{x})$ were also synthesized ac- cording to the same procedure. The $(E)$-form of these derivatives was confirmed by the NMR spectra (Fig. 2). A nuclear Overhauser effect (NOE) between the allyl proton and aromatic protons was observed, but an NOE between the allyl proton and vinyl proton was not observed. The structure of 4x was confirmed by using a heteronuclear multiple-bond correlation spectrum (HMBC), a heteronuclear multiple quantum coherence spectrum (HMQC) and an NOE study. The chemical shifts (ppm) in the ${ }^{1} \mathrm{H}$ - and ${ }^{13} \mathrm{C}-\mathrm{NMR}$ spectra of $\mathbf{4 x}$ are shown in Fig. 2.

\section{Results and Discussion}

Compounds have been evaluated in vitro for their affinity toward cloned human $\mathrm{ET}_{\mathrm{A}}$ and $\mathrm{ET}_{\mathrm{B}}$ receptors expressed in COS-1 cells employing receptor-binding assays. Some compounds were further examined in vivo for their ability after oral or intravenous administration to inhibit an increase in mean arterial blood pressure (MABP) due to the administration of exogenous big ET-1 to pithed or conscious rats.

The SARs of our novel series of ET receptor antagonists 


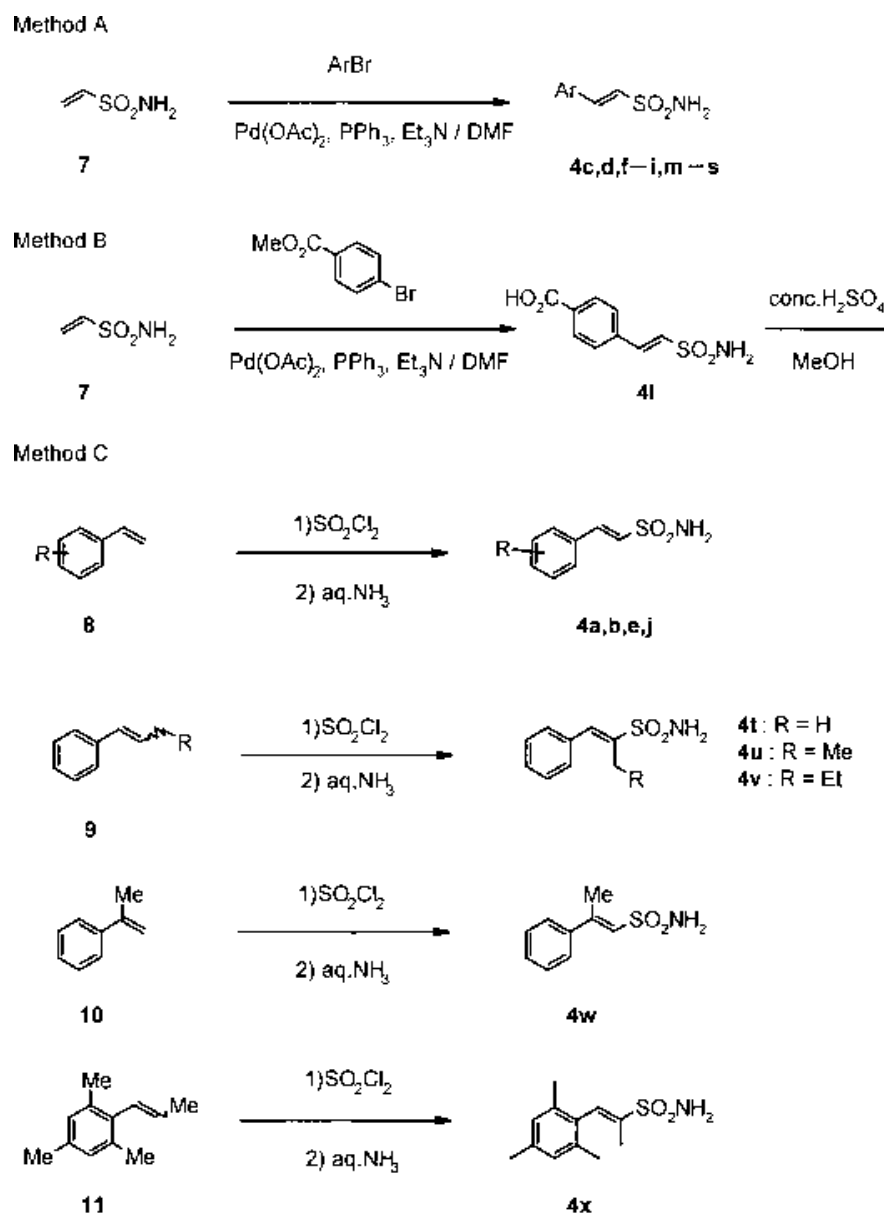

$I B U=$ teft-Butyl, TFA = trifluoroacetic acid,

Chart 2<smiles>[R]C1CCc2ccccc2C=C1S(N)(=O)=O</smiles>

NOE 4t: $: \mathrm{R} \quad \mathrm{ll}$

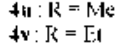

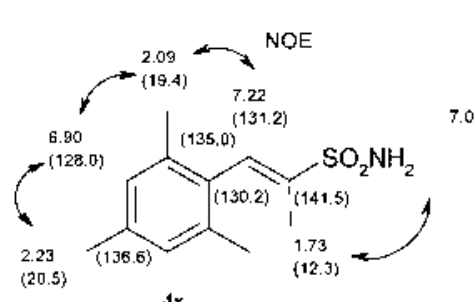

$d x$

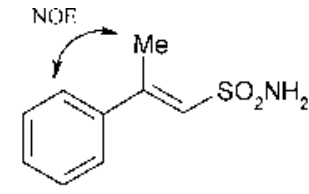

In

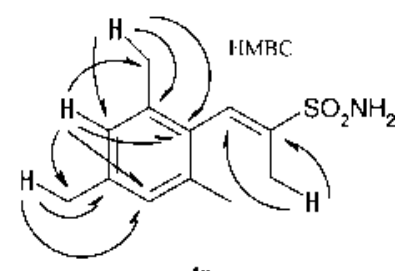

Fig. 2. Confirmation of the Structure of $4 \mathbf{t}-\mathbf{x}$

The arrow shows that the NOE between the two protons was observed. The values in the structure $4 \mathbf{x}$ show the chemical shifts (ppm) in ${ }^{1} \mathrm{H}-\mathrm{NMR}$ spectrum and the values in parentheses show the chemical shifts (ppm) in ${ }^{13} \mathrm{C}-\mathrm{NMR}$ spectrum.

are summarized in Tables $1-4$.

Mono-substitution at the $2-4$ position of the phenyl ring was investigated (Table 1). Introduction of a methyl group into the phenyl ring of the 2-phenylethenesulfonamide moiety $(\mathbf{6 a}-\mathbf{c})$ retained the same order of the affinity for the
$\mathrm{ET}_{\mathrm{A}}$ receptor compared with 1a and $\mathbf{b}$. On the other hand, the 2-methyl derivative 6a and the 4-methyl derivative $\mathbf{6 c}$ resulted in an increase in the $\mathrm{ET}_{\mathrm{B}}$ binding affinity over the compound 1a by 4-fold and 6-fold respectively. For the chlorine substitution, the 2- and 4-positions $(\mathbf{6 d}, \mathbf{f})$ also showed 
Table 1. $\mathrm{ET}_{\mathrm{A}}$ and $\mathrm{ET}_{\mathrm{B}}$ Receptor Binding Affinities for Ethenesulfonamide Derivatives

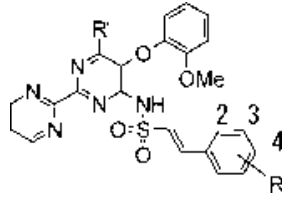

\begin{tabular}{llll}
\hline \hline Compound & $\mathrm{R}$ & $\mathrm{R}^{\prime} \quad \frac{\mathrm{IC}_{50}(\mathrm{nM})^{a)}}{\mathrm{ET}_{\mathrm{A}}{ }^{b)} \quad \mathrm{ET}_{\mathrm{B}}{ }^{b)}}$ & $\begin{array}{c}\text { Selectivity } \\
\text { for } \\
\mathrm{ET}_{\mathrm{A}}{ }^{c)}\end{array}$
\end{tabular}

\begin{tabular}{lccrrr}
\hline $\mathbf{1 a}^{()}$ & $\mathrm{H}$ & $\mathrm{MeO}$ & 3.1 & 1200 & 390 \\
$\mathbf{1 b}^{()}$ & $\mathrm{H}$ & $\mathrm{HO}\left(\mathrm{CH}_{2}\right)_{2} \mathrm{O}-$ & 1.6 & 370 & 231 \\
$\mathbf{6 a}$ & $2-\mathrm{Me}$ & $\mathrm{MeO}$ & 1.9 & 320 & 170 \\
$\mathbf{6 b}$ & $3-\mathrm{Me}$ & $\mathrm{HO}\left(\mathrm{CH}_{2}\right)_{2} \mathrm{O}-$ & 7.6 & 360 & 50 \\
$\mathbf{6} \mathbf{c}$ & $4-\mathrm{Me}$ & $\mathrm{MeO}$ & 2.8 & 190 & 68 \\
$\mathbf{6 d}$ & $2-\mathrm{Cl}$ & $\mathrm{MeO}$ & 2.3 & 270 & 120 \\
$\mathbf{6 e}$ & $3-\mathrm{Cl}$ & $\mathrm{MeO}$ & 2.2 & 770 & 330 \\
$\mathbf{6} \mathbf{f}$ & $4-\mathrm{Cl}$ & $\mathrm{MeO}$ & 13 & 280 & 22 \\
$\mathbf{6 g}$ & $4-\mathrm{Et}$ & $\mathrm{MeO}$ & 11 & 580 & 52 \\
$\mathbf{6} \mathbf{h}^{e)}$ & $4-t e r t-\mathrm{Bu}$ & $\mathrm{MeO}$ & 120 & 350 & 2.9 \\
$\mathbf{6 i}^{\mathbf{6}}$ & $4-\mathrm{MeO}$ & $\mathrm{MeO}$ & 13 & 320 & 25 \\
$\mathbf{6 j}^{e}$ & $4-\mathrm{CF} \mathrm{F}_{3}$ & $\mathrm{MeO}$ & 38 & 350 & 9.2 \\
$\mathbf{6 k}$ & $4-\mathrm{COOMe}$ & $\mathrm{MeO}$ & 12 & 650 & 54 \\
$\mathbf{6}$ & $4-\mathrm{COOH}$ & $\mathrm{MeO}$ & 140 & $>1000$ & \\
& & & & &
\end{tabular}

a) Experiments were performed twice except 1a for $\mathrm{ET}_{\mathrm{A}}$ and $\mathrm{ET}_{\mathrm{B}}, \mathbf{6 w}$ for $\mathrm{ET}_{\mathrm{A}}$. b) Cloned human receptor binding. c) Expressed as $\mathrm{ET}_{\mathrm{B}} \mathrm{IC}_{50} / \mathrm{ET}_{\mathrm{A}} \mathrm{IC}_{50} . d$ ) The biological data of compound was previously reported (see ref. 8). e) Potassium salt.

Table 2. $\mathrm{ET}_{\mathrm{A}}$ and $\mathrm{ET}_{\mathrm{B}}$ Receptor Binding Affinities for Ethenesulfonamide Derivatives

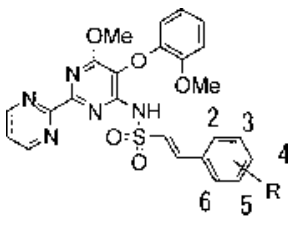

\begin{tabular}{|c|c|c|c|c|}
\hline \multirow{2}{*}{ Compound } & \multirow{2}{*}{$\mathrm{R}$} & \multicolumn{2}{|c|}{$\mathrm{IC}_{50}(\mathrm{nM})^{a)}$} & \multirow{2}{*}{$\begin{array}{c}\text { Selectivity } \\
\text { for } \\
\mathrm{ET}_{\mathrm{A}}{ }^{c)}\end{array}$} \\
\hline & & $\mathrm{ET}_{\mathrm{A}}^{b)}$ & $\mathrm{ET}_{\mathrm{B}}^{b)}$ & \\
\hline $1 \mathbf{a}^{d)}$ & $\mathrm{H}$ & 3.1 & 1200 & 390 \\
\hline $\mathbf{6 a}$ & 2-Me & 1.9 & 320 & 170 \\
\hline $6 \mathrm{~m}$ & 2,3-di-Me & 3.6 & 290 & 81 \\
\hline $6 n$ & 2,4-di-Me & 2.2 & 93 & 42 \\
\hline 60 & 2,5-di-Me & 37 & 340 & 9.1 \\
\hline $6 p$ & 2,6-di-Me & 8.7 & 74 & 8.5 \\
\hline $6 q$ & 2,6-di-Et & 26 & 180 & 6.9 \\
\hline $6 r$ & 2,6-di-Cl & 4.6 & 160 & 35 \\
\hline $6 s$ & 2,4,6-tri-Me & 2.2 & 30 & 14 \\
\hline
\end{tabular}

$a-d)$ See footnotes in Table 1.

an increase in the $\mathrm{ET}_{\mathrm{B}}$ binding affinity by 4-fold.

Realizing the effectiveness of 4-substitution in increasing the $\mathrm{ET}_{\mathrm{B}}$ binding affinity, we then synthesized and evaluated a series of compounds with another substitutions at the 4position. The ethyl, tert-butyl, methoxy, trifluoromethyl and methoxycarbonyl derivatives $(\mathbf{6 g}-\mathbf{k})$ were more potent in $\mathrm{ET}_{\mathrm{B}}$ binding affinity than 1a by 2 - to 4-fold. On the other hand, the $\mathrm{ET}_{\mathrm{A}}$ binding affinities of these 4-substituted analogues $(\mathbf{6 f}-\mathbf{k})$ were less potent than that of $\mathbf{1 a}$ by 4 - to 40 fold. These results suggested that substituents at the 4-position larger than a methyl group were not well tolerated in the $\mathrm{ET}_{\mathrm{A}}$ binding affinity, probably due to the steric factors. The
Table 3. $\mathrm{ET}_{\mathrm{A}}$ and $\mathrm{ET}_{\mathrm{B}}$ Receptor Binding Affinities for Ethenesulfonamide Derivatives

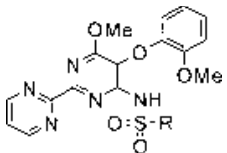

\begin{tabular}{|c|c|c|c|c|}
\hline \multirow{2}{*}{ Compound } & \multirow{2}{*}{$\mathrm{R}$} & \multicolumn{2}{|c|}{$\left.\mathrm{IC}_{50}(\mathrm{nM})^{a}\right)$} & \multirow{2}{*}{$\begin{array}{c}\text { Selectivity } \\
\text { for } \\
\mathrm{ET}_{\mathrm{A}}{ }^{c}\end{array}$} \\
\hline & & $\left.\mathrm{ET}_{\mathrm{A}}{ }^{b}\right)$ & $\left.\mathrm{ET}_{\mathrm{B}}{ }^{b}\right)$ & \\
\hline $1 \mathbf{a}^{d)}$ & & 3.1 & 1200 & 390 \\
\hline $6 t$ & & 1.6 & 310 & 190 \\
\hline $6 \mathbf{u}^{e)}$ & & 3.3 & 790 & 240 \\
\hline $6 \mathbf{v}^{e)}$ & & 170 & $>1000$ & \\
\hline $6 w$ & & 11 & 760 & 69 \\
\hline
\end{tabular}

Table 4. $\mathrm{ET}_{\mathrm{A}}$ and $\mathrm{ET}_{\mathrm{B}}$ Receptor Binding Affinities for Ethenesulfonamide Derivatives

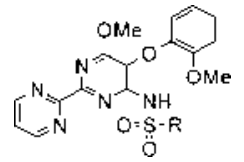

\begin{tabular}{|c|c|c|c|c|}
\hline \multirow{2}{*}{ Compound } & \multirow{2}{*}{$\mathrm{R}$} & \multicolumn{2}{|c|}{$\mathrm{IC}_{50}(\mathrm{nM})^{a)}$} & \multirow{2}{*}{$\begin{array}{c}\text { Selectivity } \\
\text { for } \\
\mathrm{ET}_{\mathrm{A}}{ }^{c)}\end{array}$} \\
\hline & & $\mathrm{ET}_{\mathrm{A}}^{b)}$ & $\mathrm{ET}_{\mathrm{B}}^{b)}$ & \\
\hline $1 \mathbf{a}^{d)}$ & & 3.1 & 1200 & 390 \\
\hline $6 s$ & & 2.2 & 30 & 14 \\
\hline $6 x$ & & 6.2 & 130 & 21 \\
\hline
\end{tabular}

$a-d)$ See footnotes in Table 1 .

acid derivative $\mathbf{6} \mathbf{l}$ was much less potent in both $\mathrm{ET}_{\mathrm{A}}$ and $\mathrm{ET}_{\mathrm{B}}$ binding affinity than 1a, indicating that acidic groups may not be tolerated at this position.

Because 2-methyl derivative 6a showed a potent $\mathrm{ET}_{\mathrm{A}}$ binding affinity and an increased $\mathrm{ET}_{\mathrm{B}}$ binding affinity, we decided to investigate additional methyl substitutions to 2-methyl derivative 6a (Table 2). Methyl substitution at the 3- and 5-positions $(\mathbf{6 m}, \mathbf{0})$ had no effect on the $\mathrm{ET}_{\mathrm{B}}$ binding affinity, while an additional methyl substitution at the 4- and 6-positions $(\mathbf{6 n}, \mathbf{p})$ increased the $\mathrm{ET}_{\mathrm{B}}$ binding affinity compared to 6a by 3- and 4-fold, respectively. The 2,4- and 2,6-dimethyl derivatives $6 \mathbf{n}$ and $\mathbf{6 p}$ retained reasonable $\mathrm{ET}_{\mathrm{A}}$ binding affinity. The $\mathrm{ET}_{\mathrm{A}}$ selectivity of $\mathbf{6 p}$ was 8.5 and lower than that of 1a by 49-fold. Replacement of the methyl groups in $\mathbf{6 p}$ with ethyl groups (6q) or chlorine atoms (6r) led to a slight decrease in the $\mathrm{ET}_{\mathrm{B}}$ binding affinity. The $\mathrm{ET}_{\mathrm{A}}$ binding affinities of $\mathbf{6 q}$ and $\mathbf{6 r}$ were lower than that of $\mathbf{6 a}$ by about 14-fold and 2 -fold, respectively. Introduction of the third methyl group at 
<smiles>[R]/C(=C\c1c(C)cc(C)cc1C)C(=O)O</smiles>

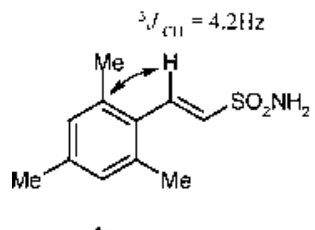

48

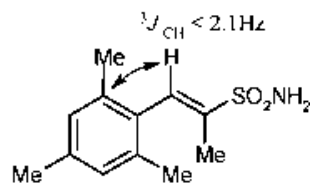

$4 x$
Fig. 3. The NMR Studies of $\mathbf{4 s}$ and $\mathbf{4 x}$

the 4-position of $\mathbf{6 p}$ afforded the trimethyl derivative $\mathbf{6 s}$ and resulted in an increase in both $\mathrm{ET}_{\mathrm{A}}$ and $\mathrm{ET}_{\mathrm{B}}$ binding affinity by $c a$. 4-fold and 2-fold, respectively. Compound 6s had a potent $\mathrm{ET}_{\mathrm{A}}$ binding affinity and a low $\mathrm{ET}_{\mathrm{A}}$ selectivity, with an $\mathrm{IC}_{50}$ value of $2.2 \mathrm{nM}$ for the $\mathrm{ET}_{\mathrm{A}}$ receptor and an $\mathrm{ET}_{\mathrm{B}} / \mathrm{ET}_{\mathrm{A}}$ ratio of 14. It was found that 2,4,6-trimethyl substitution of $1 \mathrm{a}$ increased the $\mathrm{ET}_{\mathrm{B}}$ binding affinity by 40 -fold.

We were then curious to explore the introduction of alkyl groups into the ethenyl moiety in the 2-phenylethenesulfonamide (Table 3).

Methyl substitution at the 1-position of the ethenyl moiety (6t) increased the both $\mathrm{ET}_{\mathrm{A}}$ and $\mathrm{ET}_{\mathrm{B}}$ binding affinity compared to $1 \mathrm{a}$ by about 2-fold and 4-fold, respectively. Replacement of the methyl group in 6t with the ethyl group (6u) led to $c a$. a 2-fold decrease in both $\mathrm{ET}_{\mathrm{A}}$ and $\mathrm{ET}_{\mathrm{B}}$ binding affinities. The 1-propyl derivative (6v) was significantly less active than $1 \mathbf{a}$ in both $\mathrm{ET}_{\mathrm{A}}$ and $\mathrm{ET}_{\mathrm{B}}$ binding affinities. The 2-methyl derivative (6w) was found to be almost equally potent to $\mathbf{1 a}$ in the $\mathrm{ET}_{\mathrm{B}}$ binding affinity but was about 4-fold less potent than 1 in the $\mathrm{ET}_{\mathrm{A}}$ binding affinity.

Compounds in Table 4 exemplify combination of the groups from two sites of the 2-phenylethenesulfonamide moiety.

Introduction of a methyl group at the 1-position of the ethenesulfonamide in the trimethyl derivative $\mathbf{6 s}$ gave the compound $\mathbf{6 x}$ with $c a$. a 3-fold decrease in the $\mathrm{ET}_{\mathrm{A}}$ binding affinity and a 4 -fold decrease in the $\mathrm{ET}_{\mathrm{B}}$ binding affinity. We assumed that these decreases might be due to the changes in the conformation in the 2-phenylethenesulfonamide region in 6s and 6x.

In order to investigate the differences in the stable conformation of the 2-phenylethenesulfonamide region between $\mathbf{6 s}$ and $\mathbf{6 x}$, molecular mechanics studies and NMR studies were performed using $\mathbf{4 s}$ and $\mathbf{4 x}$ as simple models (Fig. 3). A conformational analysis using a systematic search in which the torsion angle of the $\mathrm{C} 1-\mathrm{C} 2-\mathrm{C} 3-\mathrm{C} 4$ bond was rotated in $1^{\circ}$ increments revealed that the torsion angles $(\mathrm{C} 1-\mathrm{C} 2-\mathrm{C} 3-\mathrm{C} 4)$ of the most energetically favored conformations of $4 s$ and $4 x$ were $59^{\circ}$ and $90^{\circ}$, respectively (Windows CAChe version 4.4 MM2, Fujitsu Limited). In the NMR studies, the coupling constants $\left({ }^{3} J_{\mathrm{CH}}\right)$ between $\mathrm{H} 2$ and $\mathrm{C} 4$ obtained by long-range selective proton decoupling (LSPD) experiments were $4.2 \mathrm{~Hz}$ for $4 \mathbf{s}$ and $<2.1 \mathrm{~Hz}$ for $4 \mathbf{x}$. The value of the coupling constant $<2.1 \mathrm{~Hz}$ indicated that the torsion angle $(\mathrm{H} 2-\mathrm{C} 2-$

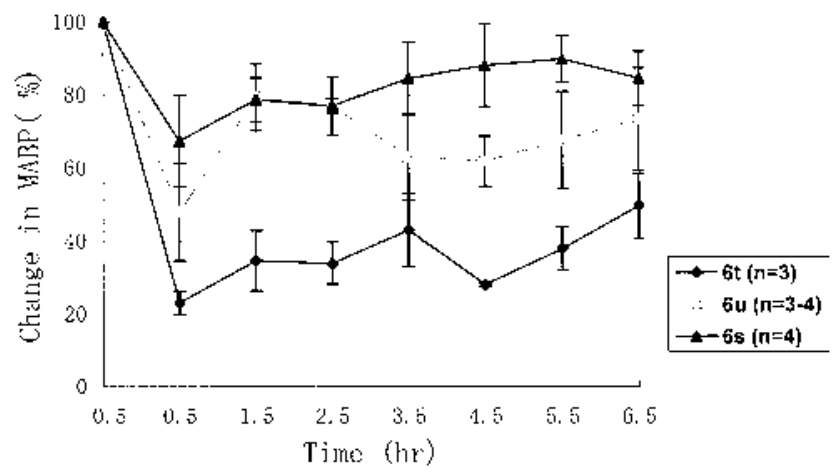

Fig. 4. Effect of oral Administration of $\mathbf{6 s}(10 \mathrm{mg} / \mathrm{kg}), \mathbf{6 t}(3 \mathrm{mg} / \mathrm{kg})$ and $\mathbf{6} \mathbf{u}$ $(0.3 \mathrm{mg} / \mathrm{kg})$ on Pressor Response to Big ET-1 in Conscious Normotensive Rats

Change in MABP (\%): increase in MABP in conscious rats elicited by intravenous administration of big ET-1 $(0.5 \mathrm{nmol} / \mathrm{kg})$.

Table 5. Comparison of the Effects of Oral Administration of the 2Phenylethenesulfonamide Derivatives on Pressor Response to Big ET-1 in Pithed Rats

\begin{tabular}{cl}
\hline \hline & \multicolumn{1}{c}{$\mathrm{ID}_{50}(\mathrm{mg} / \mathrm{kg})^{a)}$} \\
\cline { 2 - 2 } Compound & \multicolumn{1}{c}{$p . o}$. \\
\hline 6t & \multicolumn{1}{c}{$6.6(3.4-16.1)$} \\
6u & $1.7(1.1-3.0)$ \\
& $1.1(0.70-2.4)^{b)}$ \\
\hline
\end{tabular}

a) $\mathrm{ID}_{50}$ value was defined as the dose of test compounds which caused a $50 \%$ inhibition of the pressor response to big ET-1 in DBP. $n=3-8, \mathrm{ID}_{50}$ values are expressed as the mean with $95 \%$ confidence limits. b) The biological data of compound was previously reported (see ref. 8).

C3-C4) in $4 \mathbf{x}$ was about $90^{\circ}$, and the value $4.2 \mathrm{~Hz}$ indicated that the torsion angle in $4 \mathbf{s}$ was smaller than $90^{\circ} .^{12)}$ These two studies suggested that the stable conformation of the 2phenylethenesulfonamide region in $\mathbf{6 s}$ and $\mathbf{6 x}$ might be different in each compound.

We have discovered the $\mathrm{ET}_{\mathrm{A}} / \mathrm{ET}_{\mathrm{B}}$ mixed antagonist $\mathbf{6 s}$ and the $\mathrm{ET}_{\mathrm{A}}$ selective antagonists $\mathbf{6 t}$ and $\mathbf{6} \mathbf{u}$ through the SAR study around the 2-phenylethenesulfonamide region in $\mathbf{1 a}$. These compounds were further evaluated in the in vivo studies (Fig. 4, Table 5).

The trimethyl derivative $\mathbf{6 s}$, the 1-methyl derivative $\mathbf{6 t}$ and the 1-ethyl derivative $\mathbf{6 u}$ were tested for their antihypertensive activity in conscious rats after oral administration (Fig. 4). Though $6 \mathbf{s}$ showed potent binding affinity for the $\mathrm{ET}_{\mathrm{A}}$ receptor, it showed poor oral antagonistic activity. Compound 6s also showed weak antagonistic activity after intravenous administration at $10 \mathrm{mg} / \mathrm{kg}$, and the maximum inhibition of the pressor effect of big ET-1 was $45 \pm 7.6 \%$. Additional ET B $_{\mathrm{B}}$ antagonism might weaken the inhibitory activity against the pressor effect of big ET-1, ${ }^{13)}$ but the reason for the poor in vivo potency of $\mathbf{6 s}$ was not clear.

On the other hand, 6t and $\mathbf{6 u}$ showed potent activities (Fig. 4). Maximum inhibition of the pressor effect of big ET-1 after oral administration was $77 \%$ for $6 \mathrm{t}(3 \mathrm{mg} / \mathrm{kg})$ and $52 \%$ for $6 \mathbf{u}(0.3 \mathrm{mg} / \mathrm{kg})$.

Compounds $\mathbf{6 t}$ and $\mathbf{6 u}$ also inhibited the increase in MABP due to the administration of exogenous big ET-1 to anesthetized pithed rats after oral administration (Table 5). In this study, the $\mathrm{ID}_{50}$ value was defined as the dose of test com- 
Table 6. Physical Data for Compounds 4

$\mathrm{RSO}_{2} \mathrm{NH}_{2}$

\begin{tabular}{|c|c|c|c|c|c|c|}
\hline No. & $\mathrm{R}^{a)}$ & $\begin{array}{l}\operatorname{mp}\left({ }^{\circ} \mathrm{C}\right) \\
\text { (Solvent) }\end{array}$ & $\begin{array}{l}\text { Yield } \\
(\%)\end{array}$ & Method & $400 \mathrm{MHz}^{b)}{ }^{1} \mathrm{H}-\mathrm{NMR}\left(\mathrm{DMSO}-d_{6}\right)^{c)} \delta$ & $\begin{array}{l}\mathrm{FAB}^{d)} \\
\mathrm{MS} m / z\end{array}$ \\
\hline $4 a$ & & $\begin{array}{l}125-126 \\
\text { (Toluene) }\end{array}$ & 24 & $\mathrm{C}$ & $\begin{array}{l}2.38(3 \mathrm{H}, \mathrm{s}), 7.00-7.46(7 \mathrm{H}, \mathrm{m}, \text { containing, } 7.09, \mathrm{~d} \\
J=15.5 \mathrm{~Hz}), 7.62-7.72(1 \mathrm{H}, \mathrm{m})\end{array}$ & $\begin{array}{c}197 \\
\left(\mathrm{M}^{+}\right)\end{array}$ \\
\hline $4 b$ & & $\begin{array}{c}149-150 \\
(\mathrm{EtOH})\end{array}$ & 28 & $\mathrm{C}$ & $\begin{array}{l}2.33(3 \mathrm{H}, \mathrm{s}), 7.01(2 \mathrm{H}, \mathrm{s}), 7.19(1 \mathrm{H}, \mathrm{d}, J=15.0 \mathrm{~Hz}), 7.22- \\
7.39(3 \mathrm{H}, \mathrm{m}), 7.45(1 \mathrm{H}, \mathrm{d}, J=10.0 \mathrm{~Hz}), 7.48(1 \mathrm{H}, \mathrm{d}, J=15.0 \mathrm{~Hz})\end{array}$ & $\begin{array}{c}197 \\
\left(\mathrm{M}^{+}\right)\end{array}$ \\
\hline $4 c$ & & & & & See ref. 14 & \\
\hline $4 d$ & & & & & See ref. 11 & \\
\hline $4 e$ & & $\begin{array}{c}139-140 \\
(\text { EtOAc-Hex) }\end{array}$ & 36 & $\mathrm{C}$ & $5.84(2 \mathrm{H}, \mathrm{s}), 7.89(1 \mathrm{H}, \mathrm{d}, J=16.0 \mathrm{~Hz}), 7.31-7.51(5 \mathrm{H}, \mathrm{m})$. & $218\left(\mathrm{M}^{+}+1\right)$ \\
\hline $4 f$ & & & & & See ref. 14 & \\
\hline $4 \mathrm{~g}$ & & $\begin{array}{c}100-101 \\
\left(\mathrm{Et}_{2} \mathrm{O}\right)\end{array}$ & 73 & A & $\begin{array}{l}1.18(3 \mathrm{H}, \mathrm{t}, J=4.1 \mathrm{~Hz}), 2.67(2 \mathrm{H}, \mathrm{q}, J=4.1 \mathrm{~Hz}), 7.00-7.35 \\
(6 \mathrm{H}, \mathrm{m}, \text { containing, } 7.14, \mathrm{~d}, J=16.1 \mathrm{~Hz}), 7.60(2 \mathrm{H}, \mathrm{d}, J=8.1 \mathrm{~Hz})\end{array}$ & $\begin{array}{c}212 \\
\left(\mathrm{M}^{+}+1\right)\end{array}$ \\
\hline $4 \mathrm{~h}$ & & & & & See ref. 11 & \\
\hline $4 \mathbf{i}$ & & $\begin{array}{c}130-131 \\
(\text { EtOAc-Hex })\end{array}$ & 39 & A & $\begin{array}{l}3.80(3 \mathrm{H}, \mathrm{s}), 6.80-7.15(5 \mathrm{H}, \mathrm{m}), 7.29(1 \mathrm{H}, \mathrm{d}, J=15.9 \mathrm{~Hz}) \\
7.62(2 \mathrm{H}, \mathrm{d}, J=8.8 \mathrm{~Hz})\end{array}$ & $\begin{array}{c}214 \\
\left(\mathrm{M}^{+}\right)\end{array}$ \\
\hline $4 j$ & & $\begin{array}{c}121-122 \\
(\text { EtOAc-Hex) }\end{array}$ & 35 & $\mathrm{C}$ & $\begin{array}{l}7.04(1 \mathrm{H}, \mathrm{d}, J=16.0 \mathrm{~Hz}), 7.39(2 \mathrm{H}, \mathrm{d}, J=7.7 \mathrm{~Hz}), 7.50-7.80 \\
(5 \mathrm{H}, \mathrm{m})\end{array}$ & $\begin{array}{c}251 \\
\left(\mathrm{M}^{+}\right)\end{array}$ \\
\hline $4 k$ & & $\begin{array}{c}74-75 \\
(\text { EtOAc-Hex })\end{array}$ & 29 & $\mathrm{~B}$ & $\begin{array}{l}3.94(3 \mathrm{H}, \mathrm{s}), 6.99(1 \mathrm{H}, \mathrm{d}, J=15.5 \mathrm{~Hz}), 7.50-7.66(5 \mathrm{H}, \mathrm{m}), \\
8.07(2 \mathrm{H}, \mathrm{d}, J=6.9 \mathrm{~Hz})\end{array}$ & $\begin{array}{c}242 \\
\left(\mathrm{M}^{+}+1\right)\end{array}$ \\
\hline $4 \mathrm{~m}$ & & $\begin{array}{c}58-59 \\
\left(\mathrm{Et}_{2} \mathrm{O}\right)\end{array}$ & 37 & A & $\begin{array}{l}2.26(3 \mathrm{H}, \mathrm{s}), 2.27(3 \mathrm{H}, \mathrm{s}), 7.03(1 \mathrm{H}, \mathrm{d}, J=14.8 \mathrm{~Hz}), 7.10-7.16 \\
(3 \mathrm{H}, \mathrm{m}), 7.22(1 \mathrm{H}, \mathrm{d}, J=6.8 \mathrm{~Hz}), 7.45(1 \mathrm{H}, \mathrm{d}, J=7.6 \mathrm{~Hz}) \\
7.61(1 \mathrm{H}, \mathrm{d}, J=14.8 \mathrm{~Hz})\end{array}$ & $\begin{array}{c}212 \\
\left(\mathrm{M}^{+}+1\right)\end{array}$ \\
\hline $4 n$ & & $\begin{array}{c}94-95 \\
\left(\mathrm{Et}_{2} \mathrm{O}\right)\end{array}$ & 95 & A & $\begin{array}{l}2.29(3 \mathrm{H}, \mathrm{s}), 2.34(3 \mathrm{H}, \mathrm{s}), 7.03-7.10(5 \mathrm{H}, \mathrm{m}), 7.48(1 \mathrm{H}, \mathrm{d} \\
J=15.6 \mathrm{~Hz}), 7.57(1 \mathrm{H}, \mathrm{d}, J=7.8 \mathrm{~Hz})\end{array}$ & $\begin{array}{c}212 \\
\left(\mathrm{M}^{+}+1\right)\end{array}$ \\
\hline
\end{tabular}

a) The (E) form of all compounds was confirmed by the coupling constant between vinyl protons $(J>14 \mathrm{~Hz})$ in the ${ }^{1} \mathrm{H}-\mathrm{NMR}$ spectrum. $\quad$ b) $90 \mathrm{MHz}$ for $4 \mathbf{e}, \mathbf{g}, \mathbf{k}$. c) $\mathrm{CDCl}{ }_{3}$ for $\mathbf{4 j}, \mathbf{k} . \quad$ d) EI-MS for $\mathbf{4 a}, \mathbf{b}, \mathbf{j}$.

pounds which caused a $50 \%$ inhibition of the pressor response to big ET-1 in diastolic blood pressure (DBP) (details are described in the Experimental section). Compounds 6t and $\mathbf{6 u}$ showed excellent inhibitory activities after oral administration with $\mathrm{ID}_{50}$ values of 6.6 and $1.7 \mathrm{mg} / \mathrm{kg}$, respectively. The oral activity of compound $\mathbf{6 u}$ was almost the same potent as that of $1 \mathbf{a}$, calculated from these $\mathrm{ID}_{50}$ values.

\section{Conclusions}

Investigation of the further details of SARs of the ethenesulfonamide derivative 1a led to the discovery of compounds with various $\mathrm{ET}_{\mathrm{A}}$ selectivities. Introduction of methyl groups to the phenyl group in the 2-phenylethensulfonamide moiety in 1a increased the affinity for the $\mathrm{ET}_{\mathrm{B}}$ receptor and led to the discovery of $\mathrm{ET}_{\mathrm{A}} / \mathrm{ET}_{\mathrm{B}}$ mixed $\mathrm{ET}$ antagonists, the trimethylphenyl derivative 6s (YM-95562). Unfortunately, 6s lacked potent in vivo activity. However, it could be used as a valuable tool for in vitro study. We also found that the introduction of the ethyl group at the 1-position of the ethenyl group in the 2-phenylethensulfonamide moiety afforded 6u (YM91746) and retained both $\mathrm{ET}_{\mathrm{A}}$ binding affinity and $\mathrm{ET}_{\mathrm{A}}$ selec- tivity. Compound $\mathbf{6 u}$ had a potent oral activity in the inhibition of the pressor response caused by a big ET-1 infusion in both pithed and conscious rats.

\section{Experimental}

Melting points were determined on a Yanagimoto micro melting point apparatus without correction. ${ }^{1} \mathrm{H}-\mathrm{NMR}$ spectra were recorded on a JNMLA400, LA500, and A500 spectrometers using tetramethylsilane as an internal standard. MS spectra were determined with an Hitachi M-80 or JEOL JMS-DX300 spectrometer. High resolution (HR)-MS spectra were recorded using a JEOL JMS-700T mass spectrometer. Elemental analysis data were within $\pm 0.4 \%$ of the calculated values. All organic extracts were dried over anhydrous $\mathrm{MgSO}_{4}$. Chromatographic purification was performed on Merck KGaA Silica gel $60(0.040-0.063 \mathrm{~mm})$.

The ethenesulfonamide derivatives $(\mathbf{4} \mathbf{a}-\mathbf{x})$ were prepared according to the procedures described in method $\mathrm{A}-\mathrm{C}$. The physical data and the synthetic methods for $4 \mathbf{a}-\mathbf{x}$ are shown in Tables 6 and 7 .

Method A. (E)-2-(4-Ethylphenyl)ethenesulfonamide (4g) To a solution of triphenylphosphine $(86 \mathrm{mg}, 0.328 \mathrm{mmol})$ in DMF $(10 \mathrm{ml})$ was added palladium acetate $\left(\mathrm{Pd}(\mathrm{OAc})_{2}, 35 \mathrm{mg}, 0.154 \mathrm{mmol}\right)$ at room temperature under an argon atmosphere. After stirring for $5 \mathrm{~min}$, to the mixture was added a solution of 1-bromo-4-ethylbenzene $(1.48 \mathrm{~g}, 8.00 \mathrm{mmol})$, ethenesulfonamide $(1.00 \mathrm{~g}, 9.35 \mathrm{mmol})$ and triethylamine $(3.0 \mathrm{ml}, 21.6 \mathrm{mmol})$ in DMF $(5 \mathrm{ml})$. The mixture was stirred at $130^{\circ} \mathrm{C}$ for $12 \mathrm{~h}$ and poured into $1 \mathrm{M}$ aqueous $\mathrm{HCl}$. The mixture was extracted with EtOAc, and the organic layer was 
Table 7. Physical Data for Compounds 4

\begin{tabular}{|c|c|c|c|c|c|c|}
\hline No. & $\mathrm{R}^{a)}$ & $\begin{array}{l}\operatorname{mp}\left({ }^{\circ} \mathrm{C}\right) \\
\text { (Solvent) }\end{array}$ & $\begin{array}{l}\text { Yield } \\
(\%)^{a)}\end{array}$ & Method & $400 \mathrm{MHz}^{b)}{ }^{1} \mathrm{H}-\mathrm{NMR}\left(\mathrm{DMSO}-d_{6}\right)^{c)} \delta$ & $\begin{array}{l}\mathrm{FAB}^{d)} \\
\mathrm{MS} m / z\end{array}$ \\
\hline 40 & & $\begin{array}{c}128-129 \\
\left(\mathrm{Et}_{2} \mathrm{O}\right)\end{array}$ & 93 & A & $\begin{array}{l}2.28(3 \mathrm{H}, \mathrm{s}), 2.32(3 \mathrm{H}, \mathrm{s}), 7.09(1 \mathrm{H}, \mathrm{d}, J=15.6 \mathrm{~Hz}), 7.10-7.16 \\
(4 \mathrm{H}, \mathrm{m}), 7.48(1 \mathrm{H}, \mathrm{d}, J=15.6 \mathrm{~Hz}), 7.49(1 \mathrm{H}, \mathrm{s})\end{array}$ & $\begin{array}{c}211 \\
\left(\mathrm{M}^{+}\right)\end{array}$ \\
\hline $4 p$ & & $\begin{array}{c}124-125 \\
\left(\mathrm{Et}_{2} \mathrm{O}\right)\end{array}$ & 83 & A & $\begin{array}{l}2.23(6 \mathrm{H}, \mathrm{s}), 6.74(1 \mathrm{H}, \mathrm{d}, J=15.6 \mathrm{~Hz}), 7.08-7.18(5 \mathrm{H}, \mathrm{m}), \\
7.38(1 \mathrm{H}, \mathrm{d}, J=15.6 \mathrm{~Hz})\end{array}$ & $\begin{array}{c}211 \\
\left(\mathrm{M}^{+}\right)\end{array}$ \\
\hline $4 q$ & & Yellow oil & 100 & A & $\begin{array}{l}1.13(6 \mathrm{H}, \mathrm{t}, J=7.3 \mathrm{~Hz}), 2.61(4 \mathrm{H}, \mathrm{q}, J=7.3 \mathrm{~Hz}), 6.64 \\
(1 \mathrm{H}, \mathrm{d}, J=15.6 \mathrm{~Hz}), 7.08-7.18(4 \mathrm{H}, \mathrm{m}), 7.20-7.26(1 \mathrm{H}, \mathrm{m}), \\
7.44(1 \mathrm{H}, \mathrm{d}, J=15.6 \mathrm{~Hz})\end{array}$ & $\begin{array}{c}238 \\
\left(\mathrm{M}^{+}-1\right)\end{array}$ \\
\hline $4 r$ & & $\begin{array}{c}202-203 \\
(\text { EtOAc-Hex) }\end{array}$ & 13 & A & $\begin{array}{l}7.15(1 \mathrm{H}, \mathrm{d}, J=14.8 \mathrm{~Hz}), 7.25-7.40(2 \mathrm{H}, \mathrm{m}), 7.43-7.66 \\
(4 \mathrm{H}, \mathrm{m})\end{array}$ & $\begin{array}{c}252 \\
\left(\mathrm{M}^{+}+1\right)\end{array}$ \\
\hline $4 s$ & & $\begin{array}{c}171-172 \\
(\text { EtOAc-Hex })\end{array}$ & 45 & A & $\begin{array}{l}2.29(3 \mathrm{H}, \mathrm{s}), 2.34(6 \mathrm{H}, \mathrm{s}), 4.68(2 \mathrm{H}, \mathrm{br} \mathrm{s}), 6.59(1 \mathrm{H}, \mathrm{d} \\
J=16.2 \mathrm{~Hz}), 6.96(2 \mathrm{H}, \mathrm{s}), 7.65(1 \mathrm{H}, \mathrm{d}, J=16.2 \mathrm{~Hz})\end{array}$ & $\begin{array}{c}224 \\
\left(\mathrm{M}^{+}-1\right)\end{array}$ \\
\hline $4 t$ & & $\begin{array}{c}143-144 \\
(\mathrm{EtOH})\end{array}$ & 12 & $\mathrm{C}$ & $\begin{array}{l}2.41(3 \mathrm{H}, \mathrm{d}, J=2.8 \mathrm{~Hz}), 6.85(1 \mathrm{H}, \mathrm{s}), 7.12(2 \mathrm{H}, \mathrm{s}), 7.40-7.46 \\
(3 \mathrm{H}, \mathrm{m}), 7.48-7.54(2 \mathrm{H}, \mathrm{m})\end{array}$ & $\begin{array}{c}198 \\
\left(\mathrm{M}^{+}+1\right)\end{array}$ \\
\hline $4 u$ & & $\begin{array}{c}127-128 \\
\left(\mathrm{Et}_{2} \mathrm{O}\right)\end{array}$ & 43 & $\mathrm{C}$ & $\begin{array}{l}1.21(3 \mathrm{H}, \mathrm{t}, J=7.6 \mathrm{~Hz}), 2.65(2 \mathrm{H}, \mathrm{q}, J=7.6 \mathrm{~Hz}), 7.11(2 \mathrm{H}, \mathrm{s}) \\
7.36(1 \mathrm{H}, \mathrm{s}), 7.37-7.49(5 \mathrm{H}, \mathrm{m})\end{array}$ & $\begin{array}{c}211 \\
\left(\mathrm{M}^{+}\right)\end{array}$ \\
\hline $4 v$ & & Brown oil & 59 & $\mathrm{C}$ & $\begin{array}{l}0.92(3 \mathrm{H}, \mathrm{t}, J=7.2 \mathrm{~Hz}), 1.58-1.67(2 \mathrm{H}, \mathrm{m}), 2.55-2.62 \\
(2 \mathrm{H}, \mathrm{m}), 7.07-7.11(2 \mathrm{H}, \mathrm{m}), 7.37(1 \mathrm{H}, \mathrm{s}), 7.39-7.49(5 \mathrm{H}, \mathrm{m})\end{array}$ & $\begin{array}{c}226 \\
\left(\mathrm{M}^{+}+1\right)\end{array}$ \\
\hline $4 w$ & & $\begin{array}{l}85-86 \\
\text { (Toluene) }\end{array}$ & 6.3 & $\mathrm{C}$ & $\begin{array}{l}2.41(3 \mathrm{H}, \mathrm{s}), 7.12(2 \mathrm{H}, \mathrm{s}), 7.40-7.46(3 \mathrm{H}, \mathrm{m}), 7.50-7.54 \\
(2 \mathrm{H}, \mathrm{m})\end{array}$ & $\begin{array}{c}198 \\
\left(\mathrm{M}^{+}+1\right)\end{array}$ \\
\hline $4 x$ & & $\begin{array}{l}173-174 \\
\text { (Toluene) }\end{array}$ & 36 & $\mathrm{C}$ & $\begin{array}{l}1.73(3 \mathrm{H}, \mathrm{s}), 2.09(6 \mathrm{H}, \mathrm{s}), 2.23(3 \mathrm{H}, \mathrm{s}), 6.90(2 \mathrm{H}, \mathrm{s}), 7.08 \\
(2 \mathrm{H}, \mathrm{s}), 7.22(1 \mathrm{H}, \mathrm{s})\end{array}$ & $\begin{array}{c}240 \\
\left(\mathrm{M}^{+}+1\right)\end{array}$ \\
\hline
\end{tabular}

a) The $(E)$ form of all compounds was confirmed by the coupling constant between vinyl protons $(J>14 \mathrm{~Hz})$ in the ${ }^{1} \mathrm{H}-\mathrm{NMR}$ spectrum except for $\mathbf{4 t}-\mathbf{x}$. $b$ ) $90 \mathrm{MHz}$ for $\mathbf{4 s}$. c) $\mathrm{CDCl}_{3}$ for $\mathbf{4 s .}$ d) EI-MS for $\mathbf{4 o}, \mathbf{p}, \mathbf{u}$.

washed with brine and concentrated in vacuo. The residue was chromatographed over silica gel using $40: 1 \mathrm{CHCl}_{3}-\mathrm{MeOH}$ to give a solid. The solid was washed with $\mathrm{Et}_{2} \mathrm{O}$ to give $\mathbf{4 g}(1.24 \mathrm{~g}, 73 \%)$ as a yellow solid.

Method B. Methyl (E)-4-(2-Sulfamoylethenyl)benzoate (4k) To a solution of triphenylphosphine $(100 \mathrm{mg}, 0.381 \mathrm{mmol})$ in DMF $(10 \mathrm{ml})$ was added palladium acetate $\left(\mathrm{Pd}(\mathrm{OAc})_{2}, 41 \mathrm{mg}, 0.183 \mathrm{mmol}\right)$ at room temperature under an argon atmosphere. After stirring for $5 \mathrm{~min}$, to the mixture was added a solution of methyl 4-bromobenzoate $(2.00 \mathrm{~g}, 9.30 \mathrm{mmol})$, ethenesulfonamide $(1.10 \mathrm{~g}, 10.3 \mathrm{mmol})$ and triethylamine $(3.5 \mathrm{ml}, 21.6 \mathrm{mmol})$ in DMF $(5 \mathrm{ml})$. The mixture was stirred at $140^{\circ} \mathrm{C}$ for $23 \mathrm{~h}$ and concentrated in vacuo. To the residue was added water and the mixture was acidified with $1 \mathrm{~m}$ aqueous $\mathrm{HCl}$. It was extracted with EtOAc. The organic layer was washed with brine and concentrated in vacuo to give 4-(2-sulfamoylethenyl)benzoic acid (4I). The solution of $\mathbf{4 I}$ and concentrated sulfuric acid $(0.1 \mathrm{ml}, 1.88 \mathrm{mmol})$ in $\mathrm{MeOH}(30 \mathrm{ml})$ was stirred at $70^{\circ} \mathrm{C}$ for $3 \mathrm{~d}$. The mixture was concentrated in vacuo. To the residue was added water and the mixture was extracted with EtOAc. The organic layer was washed with brine and concentrated in vacuo. The residue was chromatographed over silica gel using hexane (Hex)EtOAc $(1: 1)$ to give a solid. It was recrystallized from Hex-EtOAc to give $4 \mathbf{k}(0.65 \mathrm{~g}, 29 \%$ in 2 steps $)$ as colorless crystals.

Method C. (E)-2-(2-Methylphenyl)ethenesulfonamide (4a) To $6 \mathrm{ml}$ (77.5 mmol) of DMF was added dropwise sulfurylchloride $(5.3 \mathrm{ml}, 66.1$ $\mathrm{mmol})$ at $0{ }^{\circ} \mathrm{C}$. To the solution was added (2-methylphenyl)ethene $(5 \mathrm{ml}$, $38.8 \mathrm{mmol}$ ) at room temperature and the mixture was stirred at $80^{\circ} \mathrm{C}$ for $30 \mathrm{~min}$. The mixture was poured into ice and extracted with $\mathrm{CHCl}_{3}$, and the organic layer was washed with brine and concentrated in vacuo to give 2-(2methylphenyl)ethenesulfonyl chloride as a yellow oil $(6.17 \mathrm{~g})$. To an icecooled solution of 2-(2-methylphenyl)ethenesulfonyl chloride $(6.17 \mathrm{~g})$ in tetrahydrofuran (THF) $(25 \mathrm{ml})$ was added $29 \%$ aqueous ammonium hydroxide $(7.6 \mathrm{ml})$, and the mixture was stirred at room temperature at $12 \mathrm{~h}$. The mixture was acidified with $0.5 \mathrm{M}$ aqueous $\mathrm{HCl}$ and extracted with EtOAc.
The organic layer was washed with brine and concentrated in vacuo to give a solid. It was recrystallized from toluene to give $4 \mathbf{a}(1.80 \mathrm{~g}, 24 \%)$ as colorless crystals.

(E)- $N$-[6-Chloro-5-(2-methoxyphenoxy)-2-(pyrimidin-2-yl)pyrimidin4-yl]-2-(2-methylphenyl)ethenesulfonamide (5a) To an ice-cooled solution of (E)-2-(2-methylphenyl)ethenesulfonamide (4a) $(571 \mathrm{mg}, 2.90 \mathrm{mmol})$ in DMF $(6 \mathrm{ml})$ was added $60 \%$ sodium hydride in mineral oil $(281 \mathrm{mg}$, $7.03 \mathrm{mmol}$ ) and the mixture was stirred for $10 \mathrm{~min}$ at room temperature. To the mixture 4,6-dichloro-5-(2-methoxyphenoxy)pyrimidine (3) (1.01 g, 2.89 mmol) was added, and the mixture was stirred for $2 \mathrm{~h}$ at room temperature. It was poured into ice-water and acidified with $1 \mathrm{~m}$ aqueous $\mathrm{HCl}$. The mixture was extracted with EtOAc, and the organic layer was washed with brine and concentrated in vacuo to give a brown residue. It was crystallized from EtOH to give 5a $(1.16 \mathrm{~g}, 78 \%), \mathrm{mp} 192-193^{\circ} \mathrm{C}, 400 \mathrm{MHz}{ }^{1} \mathrm{H}-\mathrm{NMR}$ $\left(\right.$ DMSO- $\left.d_{6}\right) \delta: 2.36(3 \mathrm{H}, \mathrm{s}), 3.81(3 \mathrm{H}, \mathrm{s}), 6.83(1 \mathrm{H}, \mathrm{dd}, J=1.6,8.1 \mathrm{~Hz})$, $6.85-6.90(1 \mathrm{H}, \mathrm{m}), 7.06-7.12(1 \mathrm{H}, \mathrm{m}), 7.14(1 \mathrm{H}, \mathrm{dd}, J=1.1,8.1 \mathrm{~Hz})$, $7.25-7.30(2 \mathrm{H}, \mathrm{m}), 7.32-7.37(1 \mathrm{H}, \mathrm{m}), 7.70(1 \mathrm{H}, \mathrm{t}, J=3.9 \mathrm{~Hz}), 7.75(1 \mathrm{H}$, d, $J=7.0 \mathrm{~Hz}), 7.83-7.87(1 \mathrm{H}, \mathrm{m}), 7.92(1 \mathrm{H}, \mathrm{d}, J=16.1 \mathrm{~Hz}), 9.04(2 \mathrm{H}, \mathrm{d}$, $J=3.9 \mathrm{~Hz})$. FAB-MS $m / z: 510\left(\mathrm{M}^{+}+1\right)$.

The chloropyrimidine derivatives $(\mathbf{5 b}-\mathbf{j}, \mathbf{m}-\mathbf{x})$ were prepared according to the same procedure as $\mathbf{5} \mathbf{a}$ using the corresponding ethenesulfonamide derivatives $(\mathbf{4} \mathbf{b}-\mathbf{j}, \mathbf{m}-\mathbf{x})$.

(E)- $N$-[6-Chloro-5-(2-methoxyphenoxy)-2-(pyrimidin-2-yl)pyrimidin-4yl]-2-(3-methylphenyl)ethenesulfonamide (5b): $780 \mathrm{mg}$ (53\%), mp 190$191{ }^{\circ} \mathrm{C}(\mathrm{EtOH}), 500 \mathrm{MHz}{ }^{1} \mathrm{H}-\mathrm{NMR}$ (DMSO- $\left.d_{6}\right) \delta: 2.32(3 \mathrm{H}, \mathrm{s}), 3.80(3 \mathrm{H}, \mathrm{s})$, $6.82(1 \mathrm{H}, \mathrm{d}, J=8.0 \mathrm{~Hz}), 6.85-6.89(1 \mathrm{H}, \mathrm{m}), 7.07-7.10(1 \mathrm{H}, \mathrm{m}), 7.13(1 \mathrm{H}$, d, $J=8.0 \mathrm{~Hz}), 7.26(1 \mathrm{H}, \mathrm{d}, J=8.0 \mathrm{~Hz}), 7.31-7.35(1 \mathrm{H}, \mathrm{m}), 7.51-7.54(2 \mathrm{H}$, $\mathrm{m}), 7.60(1 \mathrm{H}, \mathrm{t}, J=5.0 \mathrm{~Hz}), 7.80-7.90(2 \mathrm{H}, \mathrm{m}), 9.10(2 \mathrm{H}, \mathrm{d}, J=4.0 \mathrm{~Hz})$. FAB-MS $m / z: 510\left(\mathrm{M}^{+}+1\right)$.

(E)- $N$-[6-Chloro-5-(2-methoxyphenoxy)-2-(pyrimidin-2-yl)pyrimidin-4yl]-2-(4-methylphenyl)ethenesulfonamide (5c): $830 \mathrm{mg}$ (64\%), mp 257- 
$258^{\circ} \mathrm{C}(\mathrm{EtOH}), 400 \mathrm{MHz}{ }^{1} \mathrm{H}-\mathrm{NMR}$ (DMSO- $\left.d_{6}\right) \delta: 2.33(3 \mathrm{H}, \mathrm{s}), 3.80(3 \mathrm{H}, \mathrm{s})$, $6.82(1 \mathrm{H}, \mathrm{d}, J=6.8 \mathrm{~Hz}), 6.85-6.89(1 \mathrm{H}, \mathrm{m}), 7.06-7.16(2 \mathrm{H}, \mathrm{m}), 7.26(2 \mathrm{H}$, d, $J=7.2 \mathrm{~Hz}), 7.63(2 \mathrm{H}, \mathrm{d}, J=7.2 \mathrm{~Hz}), 7.72(1 \mathrm{H}, \mathrm{t}, J=4.8 \mathrm{~Hz}), 7.76-7.90$ $(2 \mathrm{H}, \mathrm{m}), 9.10(2 \mathrm{H}, \mathrm{d}, J=4.8 \mathrm{~Hz})$. FAB-MS $m / z: 510\left(\mathrm{M}^{+}+1\right)$.

(E)- $N$-[6-Chloro-5-(2-methoxyphenoxy)-2-(pyrimidin-2-yl)pyrimidin-4yl]-2-(2-chlorophenyl)ethenesulfonamide (5d): $2.98 \mathrm{~g}$ (74\%), mp 196$197{ }^{\circ} \mathrm{C}(\mathrm{EtOH}), 400 \mathrm{MHz}{ }^{1} \mathrm{H}-\mathrm{NMR}$ (DMSO- $\left.d_{6}\right) \delta: 3.81(3 \mathrm{H}, \mathrm{s}), 6.81-6.90$ $(2 \mathrm{H}, \mathrm{m}), 7.06-7.11(1 \mathrm{H}, \mathrm{m}), 7.12-7.16(1 \mathrm{H}, \mathrm{m}), 7.42-7.50(2 \mathrm{H}, \mathrm{m})$, $7.56-7.59(1 \mathrm{H}, \mathrm{m}), 7.69(1 \mathrm{H}, \mathrm{t}, J=4.8 \mathrm{~Hz}), 7.94(1 \mathrm{H}, \mathrm{dd}, J=1.0,7.5 \mathrm{~Hz})$, $7.97-8.03(2 \mathrm{H}, \mathrm{m}), 9.02(2 \mathrm{H}, \mathrm{d}, J=4.8 \mathrm{~Hz})$. FAB-MS $m / z$ : $528\left(\mathrm{M}^{+}-1\right)$.

(E)- $N$-[6-Chloro-5-(2-methoxyphenoxy)-2-(pyrimidin-2-yl)pyrimidin-4yl]-2-(3-chlorophenyl)ethenesulfonamide (5e): $1.27 \mathrm{~g}$ (84\%), mp 208$210^{\circ} \mathrm{C}(\mathrm{EtOH}), 400 \mathrm{MHz}{ }^{1} \mathrm{H}-\mathrm{NMR}$ (DMSO- $\left.d_{6}\right) \delta: 3.81(3 \mathrm{H}, \mathrm{s}), 6.82(1 \mathrm{H}$, dd, $J=1.6,8.0 \mathrm{~Hz}), 6.84-6.89(1 \mathrm{H}, \mathrm{m}), 7.06-7.11(1 \mathrm{H}, \mathrm{m}), 7.13(1 \mathrm{H}, \mathrm{dd}$, $J=1.6,8.0 \mathrm{~Hz}), 7.46-7.52(2 \mathrm{H}, \mathrm{m}), 7.69-7.75(2 \mathrm{H}, \mathrm{m}), 7.85-7.89(2 \mathrm{H}$, m), $7.98(1 \mathrm{H}, \mathrm{d}, J=15.6 \mathrm{~Hz}), 9.09(2 \mathrm{H}, \mathrm{d}, J=4.8 \mathrm{~Hz})$. FAB-MS $m / z: 530$ $\left(\mathrm{M}^{+}+1\right)$.

(E)-N-[6-Chloro-5-(2-methoxyphenoxy)-2-(pyrimidin-2-yl)pyrimidin-4yl]-2-(4-chlorophenyl)ethenesulfonamide (5f): $1.11 \mathrm{~g} \mathrm{(73 \% ),} \mathrm{mp} \mathrm{244-}$ $245^{\circ} \mathrm{C}(\mathrm{EtOH}), 400 \mathrm{MHz}{ }^{1} \mathrm{H}-\mathrm{NMR}$ (DMSO- $\left.d_{6}\right) \delta: 3.80(3 \mathrm{H}, \mathrm{s}), 6.81-6.83$ $(1 \mathrm{H}, \mathrm{m}), 6.84-6.89(1 \mathrm{H}, \mathrm{m}), 7.06-7.15(2 \mathrm{H}, \mathrm{m}), 7.53(2 \mathrm{H}, \mathrm{d}, J=8.4 \mathrm{~Hz})$, $7.71(1 \mathrm{H}, \mathrm{t}, J=4.8 \mathrm{~Hz}), 7.79(2 \mathrm{H}, \mathrm{d}, J=8.4 \mathrm{~Hz}), 7.85-7.95(2 \mathrm{H}, \mathrm{m}), 9.09$ $(2 \mathrm{H}, \mathrm{d}, J=4.8 \mathrm{~Hz})$. FAB-MS $m / z: 530\left(\mathrm{M}^{+}+1\right)$.

(E)- $N$-[6-Chloro-5-(2-methoxyphenoxy)-2-(pyrimidin-2-yl)pyrimidin-4yl]-2-(4-ethylphenyl)ethenesulfonamide $(\mathbf{5 g}): 1.11 \mathrm{~g}$ (62\%), mp 258$259^{\circ} \mathrm{C}(\mathrm{EtOH}), 400 \mathrm{MHz}{ }^{1} \mathrm{H}-\mathrm{NMR}$ (DMSO-d $\left.d_{6}\right) \delta: 1.17(3 \mathrm{H}, \mathrm{t}, J=7.7 \mathrm{~Hz}$ ), $2.62(2 \mathrm{H}, \mathrm{q}, J=7.7 \mathrm{~Hz}), 3.80(3 \mathrm{H}, \mathrm{s}), 6.79-6.91(2 \mathrm{H}, \mathrm{m}), 7.05-7.16(2 \mathrm{H}$, $\mathrm{m}), 7.29(2 \mathrm{H}, \mathrm{d}, J=8.1 \mathrm{~Hz}), 7.65(2 \mathrm{H}, \mathrm{d}, J=8.1 \mathrm{~Hz}), 7.72(1 \mathrm{H}, \mathrm{t}, J=4.5 \mathrm{~Hz})$, $7.79-7.91(2 \mathrm{H}, \mathrm{m}), 9.11(2 \mathrm{H}, \mathrm{d}, J=4.5 \mathrm{~Hz})$. FAB-MS $m / z$ : $524\left(\mathrm{M}^{+}+1\right)$.

(E)- $N$-[6-Chloro-5-(2-methoxyphenoxy)-2-(pyrimidin-2-yl)pyrimidin-4yl]-2-(4-tert-butylphenyl)ethenesulfonamide (5h): $1.05 \mathrm{~g}(67 \%), \mathrm{mp} 259-$ $260{ }^{\circ} \mathrm{C}(\mathrm{EtOH}), 400 \mathrm{MHz}{ }^{1} \mathrm{H}-\mathrm{NMR}$ (DMSO- $\left.d_{6}\right) \delta: 1.27(9 \mathrm{H}, \mathrm{s}), 3.80(3 \mathrm{H}, \mathrm{s})$, $6.82(1 \mathrm{H}, \mathrm{d}, J=7.6 \mathrm{~Hz}), 6.85-6.91(1 \mathrm{H}, \mathrm{m}), 7.06-7.16(2 \mathrm{H}, \mathrm{m}), 7.47(2 \mathrm{H}$, d, $J=8.8 \mathrm{~Hz}), 7.68(2 \mathrm{H}, \mathrm{d}, J=8.8 \mathrm{~Hz}), 7.74(1 \mathrm{H}, \mathrm{t}, J=4.8 \mathrm{~Hz}), 7.83(1 \mathrm{H}, \mathrm{d}$, $J=14.4 \mathrm{~Hz}), 7.91(1 \mathrm{H}, \mathrm{d}, J=14.4 \mathrm{~Hz}), 9.13(2 \mathrm{H}, \mathrm{d}, J=4.8 \mathrm{~Hz})$. FAB-MS $m / z$ : $552\left(\mathrm{M}^{+}+1\right)$.

(E)-N-[6-Chloro-5-(2-methoxyphenoxy)-2-(pyrimidin-2-yl)pyrimidin-4yl]-2-(4-methoxyphenyl)ethenesulfonamide (5i): $1.02 \mathrm{~g}$ (68\%), mp 227$230{ }^{\circ} \mathrm{C}(\mathrm{EtOH}), 400 \mathrm{MHz}{ }^{1} \mathrm{H}-\mathrm{NMR}$ (DMSO- $\left.d_{6}\right) \delta: 3.80(6 \mathrm{H}, \mathrm{s}), 6.81(1 \mathrm{H}, \mathrm{d}$, $J=8.0 \mathrm{~Hz}), 6.84-6.89(1 \mathrm{H}, \mathrm{m}), 7.01(2 \mathrm{H}, \mathrm{d}, J=8.8 \mathrm{~Hz}), 7.06-7.11(1 \mathrm{H}$, m), 7.12-7.16 (1H, m), 7.68-7.75 $(4 \mathrm{H}, \mathrm{m}), 7.81-7.88(1 \mathrm{H}, \mathrm{m}), 9.11(2 \mathrm{H}$, d, $J=4.8 \mathrm{~Hz})$. FAB-MS $m / z: 526\left(\mathrm{M}^{+}+1\right)$.

(E)- $N$-[6-Chloro-5-(2-methoxyphenoxy)-2-(pyrimidin-2-yl)pyrimidin-4yl]-2-(4-trifluoromethylphenyl)ethenesulfonamide $(\mathbf{5 j}): 2.18 \mathrm{~g}(70 \%), \mathrm{mp}$ $212-213{ }^{\circ} \mathrm{C}(\mathrm{EtOH}), 400 \mathrm{MHz}{ }^{1} \mathrm{H}-\mathrm{NMR}$ (DMSO- $\left.d_{6}\right) \delta: 3.81(3 \mathrm{H}, \mathrm{s}), 6.83$ $(1 \mathrm{H}, \mathrm{dd}, J=1.6,8.0 \mathrm{~Hz}), 6.84-6.90(1 \mathrm{H}, \mathrm{m}), 7.03-7.12(1 \mathrm{H}, \mathrm{m}), 7.13-$ $7.16(1 \mathrm{H}, \mathrm{m}), 7.72(1 \mathrm{H}, \mathrm{t}, J=4.8 \mathrm{~Hz}), 7.83(2 \mathrm{H}, \mathrm{d}, J=8.0 \mathrm{~Hz}), 7.92-8.01$ $(3 \mathrm{H}, \mathrm{m}), 8.05(1 \mathrm{H}, \mathrm{d}, J=15.6 \mathrm{~Hz}), 9.11(2 \mathrm{H}, \mathrm{d}, J=4.8 \mathrm{~Hz})$. FAB-MS $m / z$ : $564\left(\mathrm{M}^{+}+1\right)$.

(E)- $N$-[6-Chloro-5-(2-methoxyphenoxy)-2-(pyrimidin-2-yl)pyrimidin-4yl]-2-(2,3-dimethylphenyl)ethenesulfonamide (5m): $954 \mathrm{mg}$ (64\%), $\mathrm{mp}$ $211-212{ }^{\circ} \mathrm{C}(\mathrm{EtOH}), 400 \mathrm{MHz}{ }^{1} \mathrm{H}-\mathrm{NMR}$ (DMSO- $\left.d_{6}\right) \delta: 2.22(3 \mathrm{H}, \mathrm{s}), 2.26$ $(3 \mathrm{H}, \mathrm{s}), 3.80(3 \mathrm{H}, \mathrm{s}), 6.82(1 \mathrm{H}, \mathrm{dd}, J=1.4,8.4 \mathrm{~Hz}), 6.84-6.90(1 \mathrm{H}, \mathrm{m})$, $7.06-7.18(3 \mathrm{H}, \mathrm{m}), 7.24(1 \mathrm{H}, \mathrm{d}, J=7.4 \mathrm{~Hz}), 7.55(1 \mathrm{H}, \mathrm{d}, J=7.4 \mathrm{~Hz}), 7.69$ $(1 \mathrm{H}, \mathrm{t}, J=4.4 \mathrm{~Hz}), 7.76(1 \mathrm{H}, \mathrm{d}, J=15.1 \mathrm{~Hz}), 8.01(1 \mathrm{H}, \mathrm{d}, J=15.1 \mathrm{~Hz}), 9.02$ $(2 \mathrm{H}, \mathrm{d}, J=4.4 \mathrm{~Hz})$. FAB-MS $m / z: 524\left(\mathrm{M}^{+}+1\right)$.

(E)- $N$-[6-Chloro-5-(2-methoxyphenoxy)-2-(pyrimidin-2-yl)pyrimidin-4yl]-2-(2,4-dimethylphenyl)ethenesulfonamide (5n): $985 \mathrm{mg}$ (66\%), $\mathrm{mp}$ $222-223{ }^{\circ} \mathrm{C}(\mathrm{EtOH}), 400 \mathrm{MHz}{ }^{1} \mathrm{H}-\mathrm{NMR}$ (DMSO- $\left.d_{6}\right) \delta: 2.28(3 \mathrm{H}, \mathrm{s}), 2.32$ $(3 \mathrm{H}, \mathrm{s}), 3.80(3 \mathrm{H}, \mathrm{s}), 6.83(1 \mathrm{H}, \mathrm{dd}, J=1.6,8.0 \mathrm{~Hz}), 6.88(1 \mathrm{H}, \mathrm{dt}, J=1.6$, $8.0 \mathrm{~Hz}), 7.06-7.16(4 \mathrm{H}, \mathrm{m}), 7.65(1 \mathrm{H}, \mathrm{d}, J=8.0 \mathrm{~Hz}), 7.71(1 \mathrm{H}, \mathrm{t}$, $J=4.8 \mathrm{~Hz}), 7.80-7.90(2 \mathrm{H}, \mathrm{m}), 9.04(2 \mathrm{H}, \mathrm{d}, J=4.8 \mathrm{~Hz})$. FAB-MS $m / z: 524$ $\left(\mathrm{M}^{+}+1\right)$.

(E)- $N$-[6-Chloro-5-(2-methoxyphenoxy)-2-(pyrimidin-2-yl)pyrimidin-4yl]-2-(2,5-dimethylphenyl)ethenesulfonamide (5o): $930 \mathrm{mg}$ (62\%), $\mathrm{mp}$ $144-145^{\circ} \mathrm{C}(\mathrm{EtOH}), 400 \mathrm{MHz}{ }^{1} \mathrm{H}-\mathrm{NMR}$ (DMSO- $\left.d_{6}\right) \delta: 2.26(3 \mathrm{H}, \mathrm{s}), 2.30$ $(3 \mathrm{H}, \mathrm{s}), 3.80(3 \mathrm{H}, \mathrm{s}), 6.81-6.89(2 \mathrm{H}, \mathrm{m}), 7.06-7.11(1 \mathrm{H}, \mathrm{m}), 7.12-7.17$ $(1 \mathrm{H}, \mathrm{m}), 7.55(1 \mathrm{H}, \mathrm{s}), 7.71(1 \mathrm{H}, \mathrm{t}, J=5.2 \mathrm{~Hz}), 7.81-7.90(2 \mathrm{H}, \mathrm{m}), 9.04(2 \mathrm{H}$, d, $J=5.2 \mathrm{~Hz})$. FAB-MS $m / z: 524\left(\mathrm{M}^{+}+1\right)$.

(E)- $N$-[6-Chloro-5-(2-methoxyphenoxy)-2-(pyrimidin-2-yl)pyrimidin-4yl]-2-(2,6-dimethylphenyl)ethenesulfonamide (5p): $1.02 \mathrm{~g}(68 \%), \mathrm{mp} 214-$ $215^{\circ} \mathrm{C}(\mathrm{EtOH}), 400 \mathrm{MHz}{ }^{1} \mathrm{H}-\mathrm{NMR}$ (DMSO- $\left.d_{6}\right) \delta: 2.26(6 \mathrm{H}, \mathrm{s}), 3.80(3 \mathrm{H}, \mathrm{s})$, $6.80-6.84(1 \mathrm{H}, \mathrm{m}), 6.86-6.91(1 \mathrm{H}, \mathrm{m}), 7.06-7.19(5 \mathrm{H}, \mathrm{m}), 7.54(1 \mathrm{H}, \mathrm{d}$, $J=16.0 \mathrm{~Hz}), 7.64(1 \mathrm{H}, \mathrm{t}, J=4.8 \mathrm{~Hz}), 7.87(1 \mathrm{H}, \mathrm{d}, J=16.0 \mathrm{~Hz}), 8.95(2 \mathrm{H}, \mathrm{d}$,

\section{$J=4.8 \mathrm{~Hz})$. FAB-MS $m / z: 524\left(\mathrm{M}^{+}+1\right)$.}

(E)- $N$-[6-Chloro-5-(2-methoxyphenoxy)-2-(pyrimidin-2-yl)pyrimidin-4yl]-2-(2,6-diethylphenyl)ethenesulfonamide (5q): $560 \mathrm{mg}$ (35\%), mp 181$182^{\circ} \mathrm{C}(\mathrm{EtOH}), 400 \mathrm{MHz}{ }^{1} \mathrm{H}-\mathrm{NMR}\left(\mathrm{DMSO}-d_{6}\right) \delta: 0.98(6 \mathrm{H}, \mathrm{t}, J=7.6 \mathrm{~Hz})$, $2.53(4 \mathrm{H}, \mathrm{q}, J=7.6 \mathrm{~Hz}), 3.81(3 \mathrm{H}, \mathrm{s}), 6.85-6.90(1 \mathrm{H}, \mathrm{m}), 6.77(1 \mathrm{H}, \mathrm{d}$, $J=7.6 \mathrm{~Hz}), 7.23(1 \mathrm{H}, \mathrm{t}, J=7.6 \mathrm{~Hz}), 7.36(1 \mathrm{H}, \mathrm{d}, J=15.6 \mathrm{~Hz}), 7.63(1 \mathrm{H}, \mathrm{t}$, $J=4.8 \mathrm{~Hz}), 7.95(1 \mathrm{H}, \mathrm{d}, J=15.6 \mathrm{~Hz}), 8.94(2 \mathrm{H}, \mathrm{d}, J=4.8 \mathrm{~Hz})$. FAB-MS $m / z$ : $552\left(\mathrm{M}^{+}+1\right)$.

(E)- $N$-[6-Chloro-5-(2-methoxyphenoxy)-2-(pyrimidin-2-yl)pyrimidin-4yl]-2-(2,6-dichlorophenyl)ethenesulfonamide (5r): 369 (76\%), mp 197$199^{\circ} \mathrm{C}(\mathrm{EtOH}), 400 \mathrm{MHz}{ }^{1} \mathrm{H}-\mathrm{NMR}$ (DMSO- $\left.d_{6}\right) \delta: 3.81(3 \mathrm{H}, \mathrm{s}), 6.79(1 \mathrm{H}$, dd, $J=1.6,8.0 \mathrm{~Hz}), 6.84-6.89(1 \mathrm{H}, \mathrm{m}), 7.06-7.11(1 \mathrm{H}, \mathrm{m}), 7.13(1 \mathrm{H}, \mathrm{dd}$, $J=1.8,8.0 \mathrm{~Hz}), 7.39-7.44(1 \mathrm{H}, \mathrm{m}), 7.55(1 \mathrm{H}, \mathrm{d}, J=8.0 \mathrm{~Hz}), 7.63(1 \mathrm{H}, \mathrm{t}$, $J=4.8 \mathrm{~Hz}), 7.87(1 \mathrm{H}, \mathrm{d}, J=15.2 \mathrm{~Hz}), 7.94(1 \mathrm{H}, \mathrm{d}, J=15.2 \mathrm{~Hz}), 8.93(2 \mathrm{H}, \mathrm{d}$, $J=4.8 \mathrm{~Hz})$. FAB-MS $m / z: 564\left(\mathrm{M}^{+}+1\right)$.

(E)- $N$-[6-Chloro-5-(2-methoxyphenoxy)-2-(pyrimidin-2-yl)pyrimidin-4yl]-2-(2,4,6-trimethylphenyl)ethenesulfonamide $(\mathbf{5 s}): 1.23 \mathrm{~g} \mathrm{(80 \% ),} \mathrm{mp}$ $212-214{ }^{\circ} \mathrm{C}(\mathrm{EtOH}), 400 \mathrm{MHz}{ }^{1} \mathrm{H}-\mathrm{NMR}$ (DMSO- $\left.d_{6}\right) \delta: 2.23(3 \mathrm{H}, \mathrm{s}), 2.25$ $(6 \mathrm{H}, \mathrm{s}), 3.80(3 \mathrm{H}, \mathrm{s}), 6.80-6.83(1 \mathrm{H}, \mathrm{m}), 6.85-6.90(1 \mathrm{H}, \mathrm{m}), 6.92(2 \mathrm{H}, \mathrm{s})$, $7.07-7.12(1 \mathrm{H}, \mathrm{m}), 7.13-7.16(1 \mathrm{H}, \mathrm{m}), 7.54(1 \mathrm{H}, \mathrm{d}, J=16.0 \mathrm{~Hz}), 7.65$ $(1 \mathrm{H}, \mathrm{t}, J=4.8 \mathrm{~Hz}), 7.84(1 \mathrm{H}, \mathrm{d}, J=16.0 \mathrm{~Hz}), 8.97(2 \mathrm{H}, \mathrm{d}, J=4.8 \mathrm{~Hz})$. FABMS $m / z$ : $538\left(\mathrm{M}^{+}+1\right)$

(E)- $N$-[6-Chloro-5-(2-methoxyphenoxy)-2-(pyrimidin-2-yl)pyrimidin-4yl]-1-methyl-2-phenylethenesulfonamide (5t): $1.05 \mathrm{~g}$ (81\%), mp 203$204^{\circ} \mathrm{C}(\mathrm{EtOH}), 400 \mathrm{MHz}{ }^{1} \mathrm{H}-\mathrm{NMR}$ (DMSO- $\left.d_{6}\right) \delta: 2.20(3 \mathrm{H}, \mathrm{s}), 3.81(3 \mathrm{H}, \mathrm{s})$, $6.82(1 \mathrm{H}, \mathrm{d}, J=7.6 \mathrm{~Hz}), 6.85-6.91(1 \mathrm{H}, \mathrm{m}), 7.08(1 \mathrm{H}, \mathrm{d}, J=8.0 \mathrm{~Hz}), 7.10-$ $7.16(1 \mathrm{H}, \mathrm{m}), 7.36-7.47(6 \mathrm{H}, \mathrm{m}), 7.65(1 \mathrm{H}, \mathrm{s}), 7.97(1 \mathrm{H}, \mathrm{br} \mathrm{s}), 8.91-9.00$ $(2 \mathrm{H}, \mathrm{m})$. FAB-MS $m / z: 510\left(\mathrm{M}^{+}+1\right)$.

(E)- $N$-[6-Chloro-5-(2-methoxyphenoxy)-2-(pyrimidin-2-yl)pyrimidin-4yl]-1-ethyl-2-phenylethenesulfonamide (5u): $886 \mathrm{mg}$ (59\%), mp 194$195^{\circ} \mathrm{C}(\mathrm{EtOH}), 400 \mathrm{MHz}{ }^{1} \mathrm{H}-\mathrm{NMR}$ (DMSO- $\left.d_{6}\right) \delta: 1.12-1.22(3 \mathrm{H}, \mathrm{m})$, $2.60-2.74(2 \mathrm{H}, \mathrm{m}), 3.81(3 \mathrm{H}, \mathrm{s}), 6.79(1 \mathrm{H}, \mathrm{d}, J=7.2 \mathrm{~Hz}), 6.88(1 \mathrm{H}, \mathrm{t}$, $J=7.6 \mathrm{~Hz}), 7.09(1 \mathrm{H}, \mathrm{t}, J=7.6 \mathrm{~Hz}), 7.14(1 \mathrm{H}, \mathrm{d}, J=7.6 \mathrm{~Hz}), 7.36-7.46(5 \mathrm{H}$, m), $7.65(1 \mathrm{H}, \mathrm{s}), 7.90-8.10(1 \mathrm{H}, \mathrm{m}), 8.91-9.02(2 \mathrm{H}, \mathrm{m}), 11.99(1 \mathrm{H}, \mathrm{br} \mathrm{s})$. FAB-MS $m / z$ : $524\left(\mathrm{M}^{+}+1\right)$.

(E)-N-[6-Chloro-5-(2-methoxyphenoxy)-2-(pyrimidin-2-yl)pyrimidin-4yl]-2-phenyl-1-propylethenesulfonamide (5v): $1.11 \mathrm{~g}$ (72\%), mp 156$157{ }^{\circ} \mathrm{C}(\mathrm{EtOH}), 400 \mathrm{MHz}{ }^{1} \mathrm{H}-\mathrm{NMR}$ (DMSO- $\left.d_{6}\right) \delta: 0.85(3 \mathrm{H}, \mathrm{t}, J=7.6 \mathrm{~Hz}$ ), $1.55-1.63(2 \mathrm{H}, \mathrm{m}), 2.54-2.66(2 \mathrm{H}, \mathrm{m}), 3.81(3 \mathrm{H}, \mathrm{s}), 6.78(1 \mathrm{H}, \mathrm{d}$, $J=7.6 \mathrm{~Hz}), 6.87(1 \mathrm{H}, \mathrm{t}, J=7.6 \mathrm{~Hz}), 7.07-7.11(1 \mathrm{H}, \mathrm{m}), 7.14(1 \mathrm{H}, \mathrm{d}$, $J=8.0 \mathrm{~Hz}), 7.38-7.43(5 \mathrm{H}, \mathrm{m}), 7.65(1 \mathrm{H}, \mathrm{s}), 8.02(1 \mathrm{H}, \mathrm{br} \mathrm{s}), 8.89-9.01$ $(2 \mathrm{H}, \mathrm{m})$. FAB-MS $m / z: 538\left(\mathrm{M}^{+}+1\right)$.

(E)- $N$-[6-Chloro-5-(2-methoxyphenoxy)-2-(pyrimidin-2-yl)pyrimidin-4yl]-2-methyl-2-phenylethenesulfonamide (5w): $915 \mathrm{mg}(71 \%), \mathrm{mp}>300^{\circ} \mathrm{C}$ (EtOH), $400 \mathrm{MHz}{ }^{1} \mathrm{H}-\mathrm{NMR}$ (DMSO- $\left.d_{6}\right) \delta: 2.48(3 \mathrm{H}, \mathrm{s}), 3.80(3 \mathrm{H}, \mathrm{s})$, $6.81-6.90(3 \mathrm{H}, \mathrm{m}), 7.05-7.15(2 \mathrm{H}, \mathrm{m}), 7.20-7.35(1 \mathrm{H}, \mathrm{m}), 7.40-7.45$ $(2 \mathrm{H}, \mathrm{m}), 7.61-7.68(3 \mathrm{H}, \mathrm{m}), 9.08(2 \mathrm{H}, \mathrm{d}, J=4.8 \mathrm{~Hz})$. FAB-MS $m / z: 510$ $\left(\mathrm{M}^{+}+1\right)$.

(E)- $N$-[6-Chloro-5-(2-methoxyphenoxy)-2-(pyrimidin-2-yl)pyrimidin-4yl]-1-methyl-2-(2,4,6-trimethylphenyl)ethenesulfonamide (5x): $1.35 \mathrm{~g} \mathrm{(86 \% ),}$ mp 204-205 ${ }^{\circ} \mathrm{C}(\mathrm{EtOH}), 400 \mathrm{MHz}{ }^{1} \mathrm{H}-\mathrm{NMR}$ (DMSO- $\left.d_{6}\right) \delta: 1.84(6 \mathrm{H}, \mathrm{s})$, $2.19(3 \mathrm{H}, \mathrm{s}), 2.35(3 \mathrm{H}, \mathrm{s}), 3.80(3 \mathrm{H}, \mathrm{s}), 6.80-6.92(4 \mathrm{H}, \mathrm{m}), 7.05-7.17$ $(2 \mathrm{H}, \mathrm{m}), 7.62(1 \mathrm{H}, \mathrm{s}), 7.71-7.81(1 \mathrm{H}, \mathrm{m}), 8.86-9.02(2 \mathrm{H}, \mathrm{m})$. FAB-MS $m / z: 552\left(\mathrm{M}^{+}+1\right)$.

Methyl (E)-4-(2-\{N-[6-Chloro-5-(2-methoxyphenoxy)-2-(2-pyrimidinyl)pyrimidin-4-yl]sulfamoyl\}ethenyl)benzoate (5k) To an ice-cooled solution of methyl (E)-4-(2-sulfamoylethenyl)benzoate $(\mathbf{4 k}) \quad(650 \mathrm{mg}$, $2.69 \mathrm{mmol})$ in DMF $(10 \mathrm{ml})$ was added $60 \%$ sodium hydride in mineral oil $(220 \mathrm{mg}, 5.50 \mathrm{mmol}$ ), and the mixture was stirred for $10 \mathrm{~min}$ at room temperature. To the mixture 4,6-dichloro-5-(2-methoxyphenoxy)pyrimidine (3) $(900 \mathrm{mg}, 2.58 \mathrm{mmol})$ was added, and the mixture was stirred for $15 \mathrm{~h}$ at room temperature. To the mixture was added $60 \%$ sodium hydride in mineral oil $(60 \mathrm{mg}, 1.50 \mathrm{mmol})$, and the mixture was stirred at room temperature for $4 \mathrm{~h}$. It was poured into ice-water and acidified with $1 \mathrm{~m}$ aqueous $\mathrm{HCl}$. The resulting precipitate was collected by filtration to give a mixture of $\mathbf{5 k}$ and (E)-4-(2-\{N-[6-chloro-5-(2-methoxyphenoxy)-2-(2-pyrimidinyl)-4-pyrimidinyl]sulfamoyl $\}$ ethenyl)benzoic acid (51). All of the obtained mixture $(\mathbf{5 k}, \mathbf{l})$ and concentrated sulfuric acid $(0.2 \mathrm{ml}, 3.76 \mathrm{mmol})$ in $\mathrm{MeOH}(30 \mathrm{ml})$ were heated under reflux for $24 \mathrm{~h}$. It was then concentrated in vacuo and water was added to the residue. The resulting precipitate was collected by filtration. It was recrystallized from $\mathrm{MeOH}$ to give $\mathbf{5 k}(925 \mathrm{mg}, 65 \%), \mathrm{mp}$ $135-138^{\circ} \mathrm{C}, 400 \mathrm{MHz}{ }^{1} \mathrm{H}-\mathrm{NMR}$ (DMSO- $\left.d_{6}\right) \delta: 3.81(3 \mathrm{H}, \mathrm{s}), 3.87(3 \mathrm{H}, \mathrm{s})$, $6.82(1 \mathrm{H}, \mathrm{dd}, J=1.6,8.0 \mathrm{~Hz}), 6.86(1 \mathrm{H}, \mathrm{dt}, J=1.6,8.0 \mathrm{~Hz}), 7.06-7.11(1 \mathrm{H}$, $\mathrm{m}), 7.13(1 \mathrm{H}, \mathrm{dd}, J=1.2,8.0 \mathrm{~Hz}), 7.72(1 \mathrm{H}, \mathrm{t}, J=5.2 \mathrm{~Hz}), 7.88-7.92(2 \mathrm{H}$, 
m), $7.91(1 \mathrm{H}, \mathrm{d}, J=8.0 \mathrm{~Hz}), 7.98-8.05(3 \mathrm{H}, \mathrm{m}), 9.10(2 \mathrm{H}, \mathrm{d}, J=5.2 \mathrm{~Hz})$. FAB-MS $m / z$ : $552\left(\mathrm{M}^{+}-1\right)$.

The ethenesulfonamide derivatives $(6 \mathbf{a}-\mathbf{j}, \mathbf{6 m}-\mathbf{x})$ were prepared according to the procedures described in methods $\mathrm{D}-\mathrm{G}$ using the corresponding chloropyrimidine derivatives $(\mathbf{5 a}-\mathbf{j}, \mathbf{5 m}-\mathbf{x})$.

Method D. (E)- $N$-[6-Methoxy-5-(2-methoxyphenoxy)-2-(pyrimidin-2yl)pyrimidin-4-yl]-2-(2-methylphenyl)ethenesulfonamide (6a) Sodium $(230 \mathrm{mg}, 10.0 \mathrm{mmol})$ was added to methanol $(10 \mathrm{ml})$, and the mixture was stirred at room temperature until all sodium was dissolved. $(E)-N$-[6-chloro5-(2-methoxyphenoxy)-2-(pyrimidin-2-yl)pyrimidin-4-yl]-2-(2methylphenyl)ethenesulfonamide (5a) $(514 \mathrm{mg}, 1.01 \mathrm{mmol})$ was added to the solution and stirred at room temperature for $2 \mathrm{~h}$. It was poured into icewater and acidified with $1 \mathrm{~m}$ aqueous $\mathrm{HCl}$. The mixture was extracted with EtOAc, and the organic layer was washed with brine and concentrated in vacuo. The residue was recrystallized from EtOAc- $\mathrm{Et}_{2} \mathrm{O}-\mathrm{Hex}$ to give $6 \mathbf{a}$ (243 mg. $48 \%$ ) as colorless crystals: $\mathrm{mp} 232-233^{\circ} \mathrm{C} .400 \mathrm{MHz}{ }^{1} \mathrm{H}-\mathrm{NMR}$ $\left(\mathrm{DMSO}-d_{6}\right) \delta: 2.27(3 \mathrm{H}, \mathrm{s}), 3.81(3 \mathrm{H}, \mathrm{s}), 3.84(3 \mathrm{H}, \mathrm{s}), 6.41(1 \mathrm{H}, \mathrm{d}$, $J=7.5 \mathrm{~Hz}), 6.73(1 \mathrm{H}, \mathrm{t}, J=7.5 \mathrm{~Hz}), 6.88(1 \mathrm{H}, \mathrm{t}, J=7.5 \mathrm{~Hz}), 7.02(1 \mathrm{H}, \mathrm{d}$, $J=7.5 \mathrm{~Hz}), 7.17-7.27(3 \mathrm{H}, \mathrm{m}), 7.31(1 \mathrm{H}, \mathrm{d}, J=15.5 \mathrm{~Hz}), 7.59-7.72(2 \mathrm{H}$, m), 7.95-8.15 (1H, m), $9.00(2 \mathrm{H}, \mathrm{d}, J=4.3 \mathrm{~Hz})$. FAB-MS $m / z: 506$ $\left(\mathrm{M}^{+}+1\right)$. HR-MS Calcd for $\mathrm{C}_{25} \mathrm{H}_{24} \mathrm{~N}_{5} \mathrm{O}_{5} \mathrm{~S} m / z 506.1498\left(\mathrm{M}^{+}+1\right)$, Found 506.1478 .

Method E. (E)-N-[6-(2-Hydroxyethoxy)-5-(2-methoxyphenoxy)-2(pyrimidin-2-yl)pyrimidin-4-yl]-2-(3-methylphenyl)ethenesulfonamide (6b) Sodium $(315 \mathrm{mg}, 13.7 \mathrm{mmol})$ was added to ethyleneglycol $(7.7 \mathrm{ml}$, $137 \mathrm{mmol})$, and the mixture was stirred at $60^{\circ} \mathrm{C}$ until all sodium was dissolved. (E)- $N$-[6-chloro-5-(2-methoxyphenoxy)-2-(pyrimidin-2-yl)pyrimidin-4-yl]-2-(3-methylphenyl)ethenesulfonamide (5b) (700 mg, $1.37 \mathrm{mmol})$ was added to the solution and stirred at $80^{\circ} \mathrm{C}$ for $2.5 \mathrm{~h}$. It was poured into ice-water and $1 \mathrm{M} \mathrm{HCl}$, and the resulting precipitate was collected by filtration. The solid was chromatographed over silica gel using 20:1 $\mathrm{CHCl}_{3}-\mathrm{MeOH}$ to give an oil. It was crystallized from $\mathrm{Et}_{2} \mathrm{O}$ to give $\mathbf{6 b}$ $(533 \mathrm{mg}, 73 \%)$ : mp $167-169^{\circ} \mathrm{C} .500 \mathrm{MHz}{ }^{1} \mathrm{H}-\mathrm{NMR}$ (DMSO- $\left.d_{6}\right) \delta: 2.33$ $(3 \mathrm{H}, \mathrm{s}), 3.20-3.60(2 \mathrm{H}, \mathrm{m}), 3.83(3 \mathrm{H}, \mathrm{s}), 4.30-4.45(2 \mathrm{H}, \mathrm{m}), 4.69(1 \mathrm{H}$, brs), $6.70-6.83(2 \mathrm{H}, \mathrm{m}), 7.04-7.11(2 \mathrm{H}, \mathrm{m}), 7.26(1 \mathrm{H}, \mathrm{d}, J=7.5 \mathrm{~Hz})$, $7.32-7.34(1 \mathrm{H}, \mathrm{m}), 7.50-7.60(2 \mathrm{H}, \mathrm{m}), 7.57(1 \mathrm{H}, \mathrm{d}, J=15.5 \mathrm{~Hz}), 7.96$ $(1 \mathrm{H}, \mathrm{d}, J=15.5 \mathrm{~Hz}), 9.08(2 \mathrm{H}, \mathrm{d}, J=4.0 \mathrm{~Hz}), 11.34(1 \mathrm{H}, \mathrm{s})$. FAB-MS $m / z$ : $536\left(\mathrm{M}^{+}+1\right)$. Anal. Calcd for $\mathrm{C}_{26} \mathrm{H}_{25} \mathrm{~N}_{5} \mathrm{O}_{6} \mathrm{~S}: \mathrm{C}, 58.31 ; \mathrm{H}, 4.70 ; \mathrm{N}, 13.08 ; \mathrm{S}$, 5.99. Found: C, 58.33; H, 4.59; N, 13.08; S, 6.09.

Method F. (E)-N-[6-Methoxy-5-(2-methoxyphenoxy)-2-(pyrimidin2-yl)pyrimidin-4-yl]-2-(4-methylphenyl)ethenesulfonamide (6c) To the solution of $N$-[6-chloro-5-(2-methoxyphenoxy)-2-(pyrimidin-2-yl)pyrimidin-4-yl]-2-(4-methylphenyl)ethenesulfonamide (5c) (450 mg, $0.882 \mathrm{mmol})$ in DMF ( $5 \mathrm{ml})$ was added sodium methoxide $(477 \mathrm{mg}, 8.82 \mathrm{mmol}$ ), and the mixture was stirred at room temperature for $12 \mathrm{~h}$. It was poured into icewater and acidified with $1 \mathrm{~m} \mathrm{HCl}$. The resulting precipitate was collected by filtration. It was chromatographed over silica gel using $\mathrm{CHCl}_{3}-\mathrm{MeOH}$ $(40: 1)$ to give a solid. It was recrystallized from EtOH to give $\mathbf{6 c}$ (335 mg, 75\%): mp $165-166{ }^{\circ} \mathrm{C} .400 \mathrm{MHz}{ }^{1} \mathrm{H}-\mathrm{NMR}$ (DMSO- $\left.d_{6}\right) \delta: 2.33(3 \mathrm{H}, \mathrm{s})$, $3.83(3 \mathrm{H}, \mathrm{s}), 3.89(3 \mathrm{H}, \mathrm{s}), 6.66(1 \mathrm{H}, \mathrm{d}, J=8.0 \mathrm{~Hz}), 6.78-6.86(1 \mathrm{H}, \mathrm{m}), 7.03$ $(1 \mathrm{H}, \mathrm{t}, J=8.0 \mathrm{~Hz}), 7.09(1 \mathrm{H}, \mathrm{d}, J=8.0 \mathrm{~Hz}), 7.27(2 \mathrm{H}, \mathrm{d}, J=7.8 \mathrm{~Hz}), 7.62(2 \mathrm{H}$, d, $J=7.8 \mathrm{~Hz}), 7.69(1 \mathrm{H}, 7, J=4.0 \mathrm{~Hz}), 7.73(1 \mathrm{H}, \mathrm{d}, J=15.2 \mathrm{~Hz}), 7.91(1 \mathrm{H}, \mathrm{d}$, $J=15.2 \mathrm{~Hz}), 9.09(2 \mathrm{H}, \mathrm{d}, J=4.0 \mathrm{~Hz})$. FAB-MS $m / z: 506\left(\mathrm{M}^{+}+1\right)$. Anal. Calcd for $\mathrm{C}_{25} \mathrm{H}_{23} \mathrm{~N}_{5} \mathrm{O}_{5} \mathrm{~S}$ : C, 59.40; H, 4.59; N, 13.85; S, 6.34. Found: C, 59.25; H, 4.46; N, 13.89; S, 6.44 .

Method G. Potassium (E)- $N$-[6-Methoxy-5-(2-methoxyphenoxy)-2(pyrimidin-2-yl)pyrimidin-4-yl]-1-ethyl-2-phenylethenesulfonamidate (6u) To the solution of $N$-[6-chloro-5-(2-methoxyphenoxy)-2-(pyrimidin2-yl)pyrimidin-4-yl]-1-ethyl-2-phenylethenesulfonamide (5u) (480 mg, $0.916 \mathrm{mmol}$ ) in DMF $(5 \mathrm{ml})$ was added sodium methoxide (495 $\mathrm{mg}$, $9.16 \mathrm{mmol}$ ), and the mixture was stirred at room temperature for $5 \mathrm{~h}$. It was poured into ice-water and acidified with $1 \mathrm{~m} \mathrm{HCl}$. The resulting precipitate was collected by filtration. It was chromatographed over silica gel using $\mathrm{CHCl}_{3}-\mathrm{MeOH}(40: 1)$ to give $(E)-N$-[6-methoxy-5-(2-methoxyphenoxy)-2(pyrimidin-2-yl)pyrimidin-4-yl]-1-ethyl-2-phenylethenesulfonamide as a yellow amorphous solid $(375 \mathrm{mg}, 79 \%)$. To a solution of potassium hydroxide $(0.1 \mathrm{M}, 7.22 \mathrm{ml}, 0.722 \mathrm{mmol})$ was added $(E)-N$-[6-methoxy-5-(2methoxyphenoxy)-2-(pyrimidin-2-yl)pyrimidin-4-yl]-1-ethyl-2phenylethenesulfonamide $(375 \mathrm{mg})$. The mixture was stirred at room temperature for $30 \mathrm{~min}$ and concentrated in vacuo. The residue was crystallized from $\mathrm{Et}_{2} \mathrm{O}$ to give $6 \mathbf{u}(321 \mathrm{mg}, 60 \%)$ as yellow crystals. mp $146-150{ }^{\circ} \mathrm{C}$ $\left(\mathrm{Et}_{2} \mathrm{O}\right) .400 \mathrm{~Hz}{ }^{1} \mathrm{H}-\mathrm{NMR}\left(\mathrm{DMSO}-d_{6}\right) \delta: 1.00(3 \mathrm{H}, \mathrm{t}, J=7.2 \mathrm{~Hz}), 2.39(2 \mathrm{H}, \mathrm{q}$, $J=7.2 \mathrm{~Hz}), 3.78(3 \mathrm{H}, \mathrm{s}), 3.83(3 \mathrm{H}, \mathrm{s}), 6.41(1 \mathrm{H}, \mathrm{d}, J=8.0 \mathrm{~Hz}), 6.70-6.75$ $(1 \mathrm{H}, \mathrm{m}), 6.85-6.90(1 \mathrm{H}, \mathrm{m}), 7.00(1 \mathrm{H}, \mathrm{d}, J=7.2 \mathrm{~Hz}), 7.15-7.20(2 \mathrm{H}, \mathrm{m})$,
$7.22-7.28(1 \mathrm{H}, \mathrm{m}), 7.29-7.36(3 \mathrm{H}, \mathrm{m}), 7.54(1 \mathrm{H}, \mathrm{t}, J=4.8 \mathrm{~Hz}), 8.88$ $(2 \mathrm{H}, \mathrm{d}, J=4.8 \mathrm{~Hz})$. FAB-MS $m / z: 596\left(\mathrm{M}^{+}+\mathrm{K}\right)$. Anal. Calcd for $\mathrm{C}_{26} \mathrm{H}_{24} \mathrm{~N}_{5} \mathrm{O}_{5} \mathrm{SK} \cdot 1.0 \mathrm{H}_{2} \mathrm{O}: \mathrm{C}, 54.25 ; \mathrm{H}, 4.55 ; \mathrm{N}, 12.17 ; \mathrm{S}, 5.57$. Found: $\mathrm{C}$, $54.41 ; \mathrm{H}, 4.44 ; \mathrm{N}, 12.15 ; \mathrm{S}, 5.52$.

(E)-N-[6-Methoxy-5-(2-methoxyphenoxy)-2-(pyrimidin-2-yl)pyrimidin4-yl]-2-(2-chlorophenyl)ethenesulfonamide (6d) (Method D): $370 \mathrm{mg}$ (74\%): mp 97-98 ${ }^{\circ} \mathrm{C}$ (EtOAc-Et $\left.{ }_{2} \mathrm{O}-\mathrm{Hex}\right) .400 \mathrm{MHz}{ }^{1} \mathrm{H}-\mathrm{NMR}$ (DMSO- $d_{6}$ ) $\delta: 3.83(3 \mathrm{H}, \mathrm{s}), 3.91(3 \mathrm{H}, \mathrm{s}), 6.68(1 \mathrm{H}, \mathrm{d}, J=8.4 \mathrm{~Hz}), 6.77-6.86(1 \mathrm{H}, \mathrm{m})$, $7.03(1 \mathrm{H}, \mathrm{t}, J=7.6 \mathrm{~Hz}), 7.09(1 \mathrm{H}, \mathrm{d}, J=7.6 \mathrm{~Hz}), 7.42-7.51(2 \mathrm{H}, \mathrm{m}), 7.54$ $7.60(1 \mathrm{H}, \mathrm{m}), 7.62-7.69(1 \mathrm{H}, \mathrm{m}), 7.89-7.99(2 \mathrm{H}, \mathrm{m}), 8.14(1 \mathrm{H}, \mathrm{d}$, $J=14.0 \mathrm{~Hz}), 8.97-9.07(2 \mathrm{H}, \mathrm{m}), 11.63(1 \mathrm{H}, \mathrm{s})$. FAB-MS $m / z: 526\left(\mathrm{M}^{+}+1\right)$. HR-MS Calcd for $\mathrm{C}_{24} \mathrm{H}_{21} \mathrm{ClN}_{5} \mathrm{O}_{5} \mathrm{~S} m / z$ 526.0952 (M+1), Found 526.0953.

(E)-N-[6-Methoxy-5-(2-methoxyphenoxy)-2-(pyrimidin-2-yl)pyrimidin4-yl]-2-(3-chlorophenyl)ethenesulfonamide (6e) (Method D): $267 \mathrm{mg}$ (90\%): mp 95- $100{ }^{\circ} \mathrm{C}$ (EtOAc-Hex). $400 \mathrm{MHz}{ }^{1} \mathrm{H}-\mathrm{NMR}$ (DMSO- $\left.d_{6}\right) \delta$ : $3.83(3 \mathrm{H}, \mathrm{s}), 3.90(3 \mathrm{H}, \mathrm{s}), 6.67(1 \mathrm{H}, \mathrm{d}, J=7.2 \mathrm{~Hz}), 6.73-6.86(1 \mathrm{H}, \mathrm{m}), 7.03$ $(1 \mathrm{H}, \mathrm{t}, J=7.6 \mathrm{~Hz}), 7.09(1 \mathrm{H}, \mathrm{d}, J=8.0 \mathrm{~Hz}), 7.46-7.54(2 \mathrm{H}, \mathrm{m}), 7.67-7.91$ $(4 \mathrm{H}, \mathrm{m}), 8.11(1 \mathrm{H}, \mathrm{d}, J=15.6 \mathrm{~Hz}), 9.08(2 \mathrm{H}, \mathrm{d}, J=3.2 \mathrm{~Hz}), 11.59(1 \mathrm{H}, \mathrm{s})$. FAB-MS $m / z$ : $526\left(\mathrm{M}^{+}+1\right)$. FAB-MS $m / z:\left(\mathrm{M}^{+}+1\right)$. Anal. Calcd for $\mathrm{C}_{24} \mathrm{H}_{20} \mathrm{ClN}_{5} \mathrm{O}_{5} \mathrm{~S}$ : C, 54.81; H, 3.83; N, 13.32; S, 6.40; Cl, 6.74. Found: C, 54.57; H, 3.69; N, 13.21; S, 6.08; Cl, 6.79.

(E)-N-[6-Methoxy-5-(2-methoxyphenoxy)-2-(pyrimidin-2-yl)pyrimidin4-yl]-2-(4-chlorophenyl)ethenesulfonamide (6f) (Method F): $413 \mathrm{mg}(83 \%)$ : $\mathrm{mp} 63-64^{\circ} \mathrm{C}\left(\mathrm{Et}_{2} \mathrm{O}\right) .400 \mathrm{MHz}{ }^{1} \mathrm{H}-\mathrm{NMR}$ (DMSO-d $\left.{ }_{6}\right) \delta: 3.83(3 \mathrm{H}, \mathrm{s}), 3.89$ $(3 \mathrm{H}, \mathrm{s}), 6.67(1 \mathrm{H}, \mathrm{d}, J=7.6 \mathrm{~Hz}), 6.80-6.84(1 \mathrm{H}, \mathrm{m}), 7.03(1 \mathrm{H}, \mathrm{t}, J=8.0 \mathrm{~Hz})$, $7.09(1 \mathrm{H}, \mathrm{d}, J=8.0 \mathrm{~Hz}), 7.54(2 \mathrm{H}, \mathrm{d}, J=8.0 \mathrm{~Hz}), 7.63-7.72(1 \mathrm{H}, \mathrm{m}), 7.74-$ $7.85(3 \mathrm{H}, \mathrm{m}), 8.02(1 \mathrm{H}, \mathrm{d}, J=15.6 \mathrm{~Hz}), 9.09(2 \mathrm{H}, \mathrm{d}, J=4.0 \mathrm{~Hz}), 11.52(1 \mathrm{H}$, br s). FAB-MS $m / z$ : $526\left(\mathrm{M}^{+}+1\right)$. Anal. Calcd for $\mathrm{C}_{24} \mathrm{H}_{20} \mathrm{~N}_{5} \mathrm{O}_{5} \mathrm{SCl} \cdot 0.40 \mathrm{H}_{2} \mathrm{O}$ : C, 53.70; H, 4.37; N, 13.59; S, 5.56; Cl, 6.14. Found: C, 53.85; H, 4.32; N, 13.43; S, 5.47; Cl, 6.32 .

$(E)-N$-[6-Methoxy-5-(2-methoxyphenoxy)-2-(pyrimidin-2-yl)pyrimidin4-yl]-2-(4-ethylphenyl)ethenesulfonamide (6g) (Method F): $203 \mathrm{mg}$ (45\%): $\mathrm{mp} 104-107^{\circ} \mathrm{C}(\mathrm{MeOH}-\mathrm{EtOH}) .400 \mathrm{MHz}{ }^{1} \mathrm{H}-\mathrm{NMR}$ (DMSO- $\left.d_{6}\right) \delta: 1.18$ $(3 \mathrm{H}, \mathrm{t}, J=7.6 \mathrm{~Hz}), 2.63(2 \mathrm{H}, \mathrm{q}, J=7.6 \mathrm{~Hz}), 3.83(3 \mathrm{H}, \mathrm{s}), 3.89(3 \mathrm{H}, \mathrm{s}), 6.66$ $(1 \mathrm{H}, \mathrm{d}, J=7.6 \mathrm{~Hz}), 6.78-6.86(1 \mathrm{H}, \mathrm{m}), 7.03(1 \mathrm{H}, \mathrm{t}, J=7.6 \mathrm{~Hz}), 7.09(1 \mathrm{H}, \mathrm{d}$, $J=8.4 \mathrm{~Hz}), 7.30(2 \mathrm{H}, \mathrm{d}, J=8.0 \mathrm{~Hz}), 7.62-7.72(3 \mathrm{H}, \mathrm{m}), 7.77(1 \mathrm{H}, \mathrm{d}$, $J=15.6 \mathrm{~Hz}), 7.93(1 \mathrm{H}, \mathrm{d}, J=15.6 \mathrm{~Hz}), 9.09(2 \mathrm{H}, \mathrm{d}, J=4.8 \mathrm{~Hz}), 11.44(1 \mathrm{H}$, brs). FAB-MS m/z: $520\left(\mathrm{M}^{+}+1\right)$. Anal. Calcd for $\mathrm{C}_{26} \mathrm{H}_{25} \mathrm{~N}_{5} \mathrm{O}_{5} \mathrm{~S} \cdot 0.50 \mathrm{H}_{2} \mathrm{O}$ : C, 59.08; H, 4.96; N, 13.25; S, 6.07. Found: C, 59.38; H, 4.72; N, 13.53; S, 6.16 .

Potassium (E)- $N$-[6-Methoxy-5-(2-methoxyphenoxy)-2-(pyrimidin-2-yl)pyrimidin-4-yl]-2-(4-tert-butylphenyl)ethenesulfonamidate (6h) (Method $\mathrm{G}): 318 \mathrm{mg}(60 \%): \mathrm{mp} 155-156{ }^{\circ} \mathrm{C}\left(\mathrm{Et}_{2} \mathrm{O}\right) .400 \mathrm{MHz}{ }^{1} \mathrm{H}-\mathrm{NMR}$ (DMSO- $d_{6}$ ) $\delta: 1.28(9 \mathrm{H}, \mathrm{s}), 3.80(3 \mathrm{H}, \mathrm{s}), 3.84(3 \mathrm{H}, \mathrm{s}), 6.37-6.41(1 \mathrm{H}, \mathrm{m}), 6.70-6.76$ $(1 \mathrm{H}, \mathrm{m}), 6.84-6.90(1 \mathrm{H}, \mathrm{m}), 6.98-7.03(1 \mathrm{H}, \mathrm{m}), 7.09(1 \mathrm{H}, \mathrm{d}, J=15.6 \mathrm{~Hz})$, $7.41(2 \mathrm{H}, \mathrm{d}, J=8.0 \mathrm{~Hz}), 7.50(2 \mathrm{H}, \mathrm{d}, J=8.0 \mathrm{~Hz}), 7.63(1 \mathrm{H}, \mathrm{t}, J=4.8 \mathrm{~Hz}), 8.13$ $(1 \mathrm{H}, \mathrm{d}, J=15.6 \mathrm{~Hz}), 9.05(2 \mathrm{H}, \mathrm{d}, J=4.8 \mathrm{~Hz})$. FAB-MS $m / z: 624\left(\mathrm{M}^{+}+\mathrm{K}\right)$. Anal. Calcd for $\mathrm{C}_{28} \mathrm{H}_{28} \mathrm{~N}_{5} \mathrm{O}_{5} \mathrm{SK} \cdot 2.0 \mathrm{H}_{2} \mathrm{O}: \mathrm{C}, 54.09 ; \mathrm{H}, 5.19 ; \mathrm{N}, 11.26 ; \mathrm{S}$, 5.16. Found: C, 54.17; H, 5.02; N, 11.46; S, 5.02.

(E)-N-[6-Methoxy-5-(2-methoxyphenoxy)-2-(pyrimidin-2-yl)pyrimidin4-yl]-2-(4-methoxyphenyl)ethenesulfonamide (6i) (Method D): $248 \mathrm{mg}$ (100\%): mp 117- $123{ }^{\circ} \mathrm{C}$ (EtOAc-Hex). $400 \mathrm{MHz}{ }^{1} \mathrm{H}-\mathrm{NMR}$ (DMSO- $d_{6}$ ) $\delta$ : $3.80(3 \mathrm{H}, \mathrm{s}), 3.83(3 \mathrm{H}, \mathrm{s}), 3.89(3 \mathrm{H}, \mathrm{s}), 6.66(1 \mathrm{H}, \mathrm{d}, J=8.0 \mathrm{~Hz}), 6.78-6.85$ $(1 \mathrm{H}, \mathrm{m}), 6.99-7.06(3 \mathrm{H}, \mathrm{m}), 7.09(1 \mathrm{H}, \mathrm{d}, J=8.2 \mathrm{~Hz}), 7.64-7.72(3 \mathrm{H}, \mathrm{m})$, $7.76(1 \mathrm{H}, \mathrm{d}, J=15.6 \mathrm{~Hz}), 7.82(1 \mathrm{H}, \mathrm{d}, J=15.6 \mathrm{~Hz}), 9.09(2 \mathrm{H}, \mathrm{d}, J=4.8 \mathrm{~Hz})$, $11.36(1 \mathrm{H}, \mathrm{s})$. FAB-MS $m / z$ : $520\left(\mathrm{M}^{+}-1\right)$. HR-MS Calcd for $\mathrm{C}_{25} \mathrm{H}_{24} \mathrm{~N}_{5} \mathrm{O}_{6} \mathrm{~S}$ $m / z 522.1447\left(\mathrm{M}^{+}+1\right)$, Found 522.1467 .

Potassium (E)-N-[6-Methoxy-5-(2-methoxyphenoxy)-2-(pyrimidin-2yl)pyrimidin-4-yl]-2-(4-trifluoromethylphenyl)ethenesulfonamidate (6j) (Method G): $270 \mathrm{mg}(85 \%): \mathrm{mp} 180-185^{\circ} \mathrm{C}\left(\mathrm{Et}_{2} \mathrm{O}-\mathrm{Hex}\right) .400 \mathrm{MHz}{ }^{1} \mathrm{H}-$ NMR (DMSO- $\left.d_{6}\right) \delta: 3.80(3 \mathrm{H}, \mathrm{s}), 3.85(3 \mathrm{H}, \mathrm{s}), 6.39(1 \mathrm{H}, \mathrm{d}, J=8.0 \mathrm{~Hz})$, $6.71-6.77(1 \mathrm{H}, \mathrm{m}), 6.85-6.91(1 \mathrm{H}, \mathrm{m}), 7.01(1 \mathrm{H}, \mathrm{d}, J=7.6 \mathrm{~Hz}), 7.19(1 \mathrm{H}$, d, $J=16.4 \mathrm{~Hz}), 7.62(1 \mathrm{H}, \mathrm{t}, J=4.8 \mathrm{~Hz}), 7.78(2 \mathrm{H}, \mathrm{d}, J=8.0 \mathrm{~Hz}), 7.82-7.87$ $(2 \mathrm{H}, \mathrm{d}, J=8.0 \mathrm{~Hz}), 8.42(1 \mathrm{H}, \mathrm{d}, J=16.4 \mathrm{~Hz}), 9.06(2 \mathrm{H}, \mathrm{d}, J=4.8 \mathrm{~Hz})$. FABMS $m / z$ : $636\left(\mathrm{M}^{+}+\mathrm{K}\right)$. Anal. Calcd for $\mathrm{C}_{25} \mathrm{H}_{19} \mathrm{~F}_{3} \mathrm{~N}_{5} \mathrm{O}_{5} \mathrm{SK} \cdot 1.0 \mathrm{H}_{2} \mathrm{O}: \mathrm{C}, 48.78$; H, 3.44; N, 11.38; S, 5.21; F, 9.26. Found: C, 48.95; H, 3.32; N, 11.47; S, $5.21 ; \mathrm{F}, 9.45$.

(E)-N-[6-Methoxy-5-(2-methoxyphenoxy)-2-(pyrimidin-2-yl)pyrimidin4-yl]-2-(2,3-dimethylphenyl)ethenesulfonamide (6m) (Method F): $230 \mathrm{mg}$ (58\%): mp 96-99 ${ }^{\circ} \mathrm{C}(\mathrm{MeOH}) .400 \mathrm{MHz}{ }^{1} \mathrm{H}-\mathrm{NMR}$ (DMSO-d $) \delta: 2.21(3 \mathrm{H}$, s), $2.27(3 \mathrm{H}, \mathrm{s}), 3.83(3 \mathrm{H}, \mathrm{s}), 3.90(3 \mathrm{H}, \mathrm{s}), 6.67(1 \mathrm{H}, \mathrm{d}, J=7.4 \mathrm{~Hz}), 6.83(1 \mathrm{H}$, $\mathrm{t}, J=7.4 \mathrm{~Hz}), 7.03(1 \mathrm{H}, \mathrm{t}, J=7.7 \mathrm{~Hz}), 7.10(1 \mathrm{H}, \mathrm{d}, J=7.7 \mathrm{~Hz}), 7.12-7.20$ $(1 \mathrm{H}, \mathrm{m}), 7.24(1 \mathrm{H}, \mathrm{d}, J=7.3 \mathrm{~Hz}), 7.54(1 \mathrm{H}, \mathrm{d}, J=7.3 \mathrm{~Hz}), 7.62-7.70(1 \mathrm{H}$, m), $7.86(1 \mathrm{H}, \mathrm{d}, J=20.0 \mathrm{~Hz}), 7.94(1 \mathrm{H}, \mathrm{d}, J=20.0 \mathrm{~Hz}), 9.02(2 \mathrm{H}, \mathrm{d}$, 
$J=4.4 \mathrm{~Hz}), 11.43\left(1 \mathrm{H}\right.$, brs). FAB-MS $m / z: 520\left(\mathrm{M}^{+}+1\right)$. Anal. Calcd for $\mathrm{C}_{26} \mathrm{H}_{25} \mathrm{~N}_{5} \mathrm{O}_{5} \mathrm{~S} \cdot 1.0 \mathrm{H}_{2} \mathrm{O}: \mathrm{C}, 58.09 ; \mathrm{H}, 5.06 ; \mathrm{N}, 13.03 ; \mathrm{S}, 5.96$. Found: $\mathrm{C}$, $58.15 ; \mathrm{H}, 5.00 ; \mathrm{N}, 12.96 ; \mathrm{S}, 5.86$.

(E)-N-[6-Methoxy-5-(2-methoxyphenoxy)-2-(pyrimidin-2-yl)pyrimidin4-yl]-2-(2,4-dimethylphenyl)ethenesulfonamide (6n) (Method F): $210 \mathrm{mg}$ (53\%): mp 165-166 ${ }^{\circ} \mathrm{C}(\mathrm{MeOH}-\mathrm{EtOH}) .400 \mathrm{MHz}{ }^{1} \mathrm{H}-\mathrm{NMR}\left(\mathrm{DMSO}-d_{6}\right) \delta$ : $2.27(3 \mathrm{H}, \mathrm{s}), 2.30(3 \mathrm{H}, \mathrm{s}), 3.83(3 \mathrm{H}, \mathrm{s}), 3.90(3 \mathrm{H}, \mathrm{s}), 6.67(1 \mathrm{H}, \mathrm{d}, J=7.7 \mathrm{~Hz})$, $6.76-6.88(1 \mathrm{H}, \mathrm{m}), 6.98-7.16(4 \mathrm{H}, \mathrm{m}), 7.60-7.72(2 \mathrm{H}, \mathrm{m}), 7.78(1 \mathrm{H}, \mathrm{d}$, $J=15.3 \mathrm{~Hz}), 7.92(1 \mathrm{H}, \mathrm{d}, J=15.3 \mathrm{~Hz}), 9.03(2 \mathrm{H}, \mathrm{d}, J=4.4 \mathrm{~Hz}), 11.40(1 \mathrm{H}$, brs). FAB-MS $m / z$ : $520\left(\mathrm{M}^{+}+1\right)$. Anal. Calcd for $\mathrm{C}_{26} \mathrm{H}_{25} \mathrm{~N}_{5} \mathrm{O}_{5} \mathrm{~S}: \mathrm{C}, 60.10$; H, 4.85; N, 13.48; S, 6.17 Found: C, 59.92; H, 4.90; N, 13.62; S, 6.15.

(E)-N-[6-Methoxy-5-(2-methoxyphenoxy)-2-(pyrimidin-2-yl)pyrimidin4-yl]-2-(2,5-dimethylphenyl)ethenesulfonamide (6o) (Method F): $435 \mathrm{mg}$ (84\%): mp 93-95 ${ }^{\circ} \mathrm{C}(\mathrm{MeOH}-\mathrm{EtOH}) .400 \mathrm{MHz}{ }^{1} \mathrm{H}-\mathrm{NMR}$ (DMSO-d $\left.{ }_{6}\right) \delta$ : $2.27(3 \mathrm{H}, \mathrm{s}), 2.92(3 \mathrm{H}, \mathrm{s}), 3.83(3 \mathrm{H}, \mathrm{s}), 3.90(3 \mathrm{H}, \mathrm{s}), 6.67(1 \mathrm{H}, \mathrm{d}, J=8.4 \mathrm{~Hz})$, $6.82(1 \mathrm{H}, \mathrm{t}, J=7.6 \mathrm{~Hz}), 7.00-7.06(1 \mathrm{H}, \mathrm{m}), 7.09(1 \mathrm{H}, \mathrm{d}, J=8.4 \mathrm{~Hz}), 7.13-$ $7.18(2 \mathrm{H}, \mathrm{m}), 7.54(1 \mathrm{H}, \mathrm{s}), 7.69(1 \mathrm{H}, \mathrm{t}, J=4.0 \mathrm{~Hz}), 7.79(1 \mathrm{H}, \mathrm{d}, J=15.6 \mathrm{~Hz})$, $7.97(1 \mathrm{H}, \mathrm{d}, J=15.6 \mathrm{~Hz}), 9.03(2 \mathrm{H}, \mathrm{d}, J=4.0 \mathrm{~Hz}), 11.47(1 \mathrm{H}, \mathrm{s})$. FAB-MS $m / z: 520\left(\mathrm{M}^{+}+1\right)$. Anal. Calcd for $\mathrm{C}_{26} \mathrm{H}_{25} \mathrm{~N}_{5} \mathrm{O}_{5} \mathrm{~S} \cdot 0.5 \mathrm{H}_{2} \mathrm{O}: \mathrm{C}, 59.08 ; \mathrm{H}, 4.96$; N, 13.25; S, 6.07. Found: C, 58.80; H, 5.07; N, 13.00; S, 5.94.

(E)-N-[6-Methoxy-5-(2-methoxyphenoxy)-2-(pyrimidin-2-yl)pyrimidin4-yl]-2-(2,6-dimethylphenyl)ethenesulfonamide (6p) (Method F): $265 \mathrm{mg}$ (51\%): mp 91-92 ${ }^{\circ} \mathrm{C}(\mathrm{MeOH}) .400 \mathrm{MHz}{ }^{1} \mathrm{H}-\mathrm{NMR}$ (DMSO- $\left.d_{6}\right) \delta: 2.27(6 \mathrm{H}$, s), $3.82(3 \mathrm{H}, \mathrm{s}), 3.91(3 \mathrm{H}, \mathrm{s}), 6.66(1 \mathrm{H}, \mathrm{d}, J=8.0 \mathrm{~Hz}), 6.79-6.87(1 \mathrm{H}, \mathrm{m})$, $7.01-7.06(1 \mathrm{H}, \mathrm{m}), 7.07-7.12(3 \mathrm{H}, \mathrm{m}), 7.14-7.19(1 \mathrm{H}, \mathrm{m}), 7.56-7.65$ $(2 \mathrm{H}, \mathrm{m}), 7.81(1 \mathrm{H}, \mathrm{d}, J=16.0 \mathrm{~Hz}), 8.93(2 \mathrm{H}, \mathrm{d}, J=4.4 \mathrm{~Hz}), 11.46(1 \mathrm{H}, \mathrm{s}$,$) .$ FAB-MS $m / z$ : $520\left(\mathrm{M}^{+}+1\right)$. Anal. Calcd for $\mathrm{C}_{26} \mathrm{H}_{25} \mathrm{~N}_{5} \mathrm{O}_{5} \mathrm{~S} \cdot 0.60 \mathrm{H}_{2} \mathrm{O}: \mathrm{C}$, 58.88; H, 4.98; N, 13.20; S, 6.05. Found: C, 58.59; H, 4.81; N, 13.07; S, 5.85 .

(E)-N-[6-Methoxy-5-(2-methoxyphenoxy)-2-(pyrimidin-2-yl)pyrimidin4-yl]-2-(2,6-diethylphenyl)ethenesulfonamide (6q) (Method F): $265 \mathrm{mg}$ (51\%): mp 142-143 ${ }^{\circ} \mathrm{C}(\mathrm{MeOH}-\mathrm{EtOH}) .400 \mathrm{MHz}{ }^{1} \mathrm{H}-\mathrm{NMR}$ (DMSO- $\left.d_{6}\right) \delta$ : $0.98(6 \mathrm{H}, \mathrm{d}, J=7.6 \mathrm{~Hz}), 2.54(4 \mathrm{H}, \mathrm{q}, J=7.6 \mathrm{~Hz}), 3.83(3 \mathrm{H}, \mathrm{s}), 3.91(3 \mathrm{H}, \mathrm{s})$, $6.62(1 \mathrm{H}, \mathrm{d}, J=7.2 \mathrm{~Hz}), 6.80-6.85(1 \mathrm{H}, \mathrm{m}), 7.00-7.14(4 \mathrm{H}, \mathrm{m}), 7.23(1 \mathrm{H}$, t, $J=7.6 \mathrm{~Hz}), 7.42(1 \mathrm{H}, \mathrm{d}, J=16.0 \mathrm{~Hz}), 7.56-7.63(1 \mathrm{H}, \mathrm{m}), 7.90(1 \mathrm{H}, \mathrm{d}$, $J=16.0 \mathrm{~Hz}), 8.91(2 \mathrm{H}, \mathrm{d}, J=3.6 \mathrm{~Hz}), 11.60(1 \mathrm{H}, \mathrm{brs})$. FAB-MS $m / z: 548$ $\left(\mathrm{M}^{+}+1\right)$. Anal. Calcd for $\mathrm{C}_{28} \mathrm{H}_{29} \mathrm{~N}_{5} \mathrm{O}_{5} \mathrm{~S} \cdot 0.50 \mathrm{H}_{2} \mathrm{O}: \mathrm{C}, 60.42 ; \mathrm{H}, 5.43 ; \mathrm{N}$, 12.58; S, 5.76. Found: C, 60.57; H, 5.46; N, 12.74; S, 5.88 .

(E)-N-[6-Methoxy-5-(2-methoxyphenoxy)-2-(pyrimidin-2-yl)pyrimidin4-yl]-2-(2,6-dichlorophenyl)ethenesulfonamide (6r) (Method D): $220 \mathrm{mg}$ (89\%): mp $114-115^{\circ} \mathrm{C}(\mathrm{EtOH}) .400 \mathrm{MHz}{ }^{1} \mathrm{H}-\mathrm{NMR}$ (DMSO- $\left.d_{6}\right) \delta: 3.82$ $(3 \mathrm{H}, \mathrm{s}), 3.91(3 \mathrm{H}, \mathrm{s}), 6.65(1 \mathrm{H}, \mathrm{d}, J=7.6 \mathrm{~Hz}), 6.82(1 \mathrm{H}, \mathrm{t}, J=7.6 \mathrm{~Hz}), 7.03$ $(1 \mathrm{H}, \mathrm{t}, J=7.6 \mathrm{~Hz}), 7.09(1 \mathrm{H}, \mathrm{d}, J=7.6 \mathrm{~Hz}), 7.40-7.45(1 \mathrm{H}, \mathrm{m}), 7.56(2 \mathrm{H}, \mathrm{d}$, $J=8.0 \mathrm{~Hz}), 7.59-7.65(1 \mathrm{H}, \mathrm{m}), 7.87(1 \mathrm{H}, \mathrm{d}, J=15.2 \mathrm{~Hz}), 8.07(1 \mathrm{H}, \mathrm{d}$, $J=15.2 \mathrm{~Hz}), 8.90-8.97(2 \mathrm{H}, \mathrm{m}), 11.69(1 \mathrm{H}$, brs $)$. FAB-MS $m / z: 560$ $\left(\mathrm{M}^{+}+1\right)$. Anal. Calcd for $\mathrm{C}_{24} \mathrm{H}_{19} \mathrm{Cl}_{2} \mathrm{~N}_{5} \mathrm{O}_{5} \mathrm{~S} \cdot 1.0 \mathrm{H}_{2} \mathrm{O}: \mathrm{C}, 49.84 ; \mathrm{H}, 3.66 ; \mathrm{N}$, 12.11; S, 5.54; Cl, 12.26. Found: C, 49.62; H, 3.63; N, 12.10; S, 5.55; Cl, 12.41 .

(E)- $N$-[6-Methoxy-5-(2-methoxyphenoxy)-2-(pyrimidin-2-yl)pyrimidin4-yl]-2-(2,4,6-trimethylphenyl)ethenesulfonamide (6s) (Method D): $291 \mathrm{mg}$ (84\%): mp. $167-168^{\circ} \mathrm{C}(\mathrm{EtOH}) .400 \mathrm{MHz}{ }^{1} \mathrm{H}-\mathrm{NMR}$ (DMSO- $\left.d_{6}\right) \delta: 2.23$ $(3 \mathrm{H}, \mathrm{s}), 2.50(6 \mathrm{H}, \mathrm{s}), 3.82(3 \mathrm{H}, \mathrm{s}), 3.90(3 \mathrm{H}, \mathrm{s}), 6.65(1 \mathrm{H}, \mathrm{d}, J=8.0 \mathrm{~Hz})$, $6.80-6.85(1 \mathrm{H}, \mathrm{m}), 6.92(2 \mathrm{H}, \mathrm{s}), 7.01-7.05(1 \mathrm{H}, \mathrm{m}), 7.09(1 \mathrm{H}, \mathrm{d}$, $J=8.0 \mathrm{~Hz}), 7.57-7.65(2 \mathrm{H}, \mathrm{m}), 7.77(1 \mathrm{H}, \mathrm{d}, J=16.0 \mathrm{~Hz}), 8.95(2 \mathrm{H}, \mathrm{d}$, $J=4.8 \mathrm{~Hz}), 11.44(1 \mathrm{H}, \mathrm{s})$. FAB-MS $m / z: 534\left(\mathrm{M}^{+}+1\right)$. Anal. Calcd for $\mathrm{C}_{27} \mathrm{H}_{27} \mathrm{~N}_{5} \mathrm{O}_{5} \mathrm{~S} \cdot 0.25 \mathrm{H}_{2} \mathrm{O}: \mathrm{C}, 60.27 ; \mathrm{H}, 5.15 ; \mathrm{N}, 13.01 ; \mathrm{S}, 5.96$. Found: $\mathrm{C}$, $60.16 ; \mathrm{H}, 5.01 ; \mathrm{N}, 12.93 ; \mathrm{S}, 5.87$.

(E)-N-[6-Methoxy-5-(2-methoxyphenoxy)-2-(pyrimidin-2-yl)pyrimidin4-yl]-1-methyl-2-phenylethenesulfonamide (6t) (Method F): $340 \mathrm{mg}(67 \%)$ : mp $148-149^{\circ} \mathrm{C}\left(\mathrm{Et}_{2} \mathrm{O}-\mathrm{EtOH}\right) .400 \mathrm{MHz}{ }^{1} \mathrm{H}-\mathrm{NMR}$ (DMSO-d $) \delta: 2.22(3 \mathrm{H}$, s), $3.83(3 \mathrm{H}, \mathrm{s}), 3.87(3 \mathrm{H}, \mathrm{s}), 6.65(1 \mathrm{H}, \mathrm{d}, J=7.2 \mathrm{~Hz}), 6.81-6.86(1 \mathrm{H}, \mathrm{m})$, $7.04(1 \mathrm{H}, \mathrm{t}, J=7.6 \mathrm{~Hz}), 7.09(1 \mathrm{H}, \mathrm{d}, J=8.0 \mathrm{~Hz}), 7.34-7.43(5 \mathrm{H}, \mathrm{m}), 7.61$ $(1 \mathrm{H}, \mathrm{t}, J=4.0 \mathrm{~Hz}), 7.87(1 \mathrm{H}, \mathrm{s}), 8.91(2 \mathrm{H}, \mathrm{d}, J=4.0 \mathrm{~Hz}), 11.29(1 \mathrm{H}, \mathrm{s})$. FABMS m/z: $506\left(\mathrm{M}^{+}+1\right)$. Anal. Calcd for $\mathrm{C}_{25} \mathrm{H}_{23} \mathrm{~N}_{5} \mathrm{O}_{5} \mathrm{~S}: \mathrm{C}, 59.40 ; \mathrm{H}, 4.59 ; \mathrm{N}$, 13.85; S, 6.34. Found: C, 59.30; H, 4.56; N, 13.75; S, 6.29.

Potassium (E)-N-[6-Methoxy-5-(2-methoxyphenoxy)-2-(pyrimidin-2yl)pyrimidin-4-yl]-2-phenyl-1-propylethenesulfonamidate (6v) (Method G): $325 \mathrm{mg}(68 \%)$ : mp 93-96 ${ }^{\circ} \mathrm{C}\left(\mathrm{Et}_{2} \mathrm{O}\right) .400 \mathrm{MHz}{ }^{1} \mathrm{H}-\mathrm{NMR}$ (DMSO-d $\left.d_{6}\right) \delta$ : $0.70(3 \mathrm{H}, \mathrm{t}, J=7.2 \mathrm{~Hz}), 1.41-1.51(2 \mathrm{H}, \mathrm{m}), 2.31-2.37(2 \mathrm{H}, \mathrm{m}), 3.77(3 \mathrm{H}$, s), $3.84(3 \mathrm{H}, \mathrm{s}), 6.39(1 \mathrm{H}, \mathrm{dd}, J=1.8,8.4 \mathrm{~Hz}), 6.69-6.75(1 \mathrm{H}, \mathrm{m}), 6.84-$ $6.90(1 \mathrm{H}, \mathrm{m}), 6.98-7.02(1 \mathrm{H}, \mathrm{m}), 7.13-7.18(2 \mathrm{H}, \mathrm{m}), 7.21-7.26(1 \mathrm{H}, \mathrm{m})$, $7.29-7.35(2 \mathrm{H}, \mathrm{m}), 7.37(1 \mathrm{H}, \mathrm{s}), 7.53(1 \mathrm{H}, \mathrm{t}, J=4.8 \mathrm{~Hz}), 8.66(2 \mathrm{H}, \mathrm{d}$, $J=4.8 \mathrm{~Hz})$. FAB-MS $m / z$ : $610\left(\mathrm{M}^{+}+\mathrm{K}\right)$. HR-MS Calcd for $\mathrm{C}_{27} \mathrm{H}_{27} \mathrm{~N}_{5} \mathrm{O}_{5} \mathrm{SK}$ $m / z 572.1370\left(\mathrm{M}^{+}+1\right)$, Found 572.1355.
(E)-N-[6-Methoxy-5-(2-methoxyphenoxy)-2-(pyrimidin-2-yl)pyrimidin4-yl]-2-methyl-2-phenylethenesulfonamide (6w) (Method F): $33 \mathrm{mg}(3.0 \%)$ : $\mathrm{mp}>300^{\circ} \mathrm{C}\left(\mathrm{Et}_{2} \mathrm{O}\right) .400 \mathrm{MHz}{ }^{1} \mathrm{H}-\mathrm{NMR}\left(\mathrm{DMSO}_{6}\right) \delta: 2.23(3 \mathrm{H}, \mathrm{d}, J=$ $0.8 \mathrm{~Hz}), 3.79(3 \mathrm{H}, \mathrm{s}), 3.85(3 \mathrm{H}, \mathrm{s}), 6.39(1 \mathrm{H}, \mathrm{dd}, J=1.6,8.0 \mathrm{~Hz}), 6.70-6.75$ $(1 \mathrm{H}, \mathrm{m}), 6.85-6.90(1 \mathrm{H}, \mathrm{m}), 7.01(1 \mathrm{H}, \mathrm{dd}, J=1.6,8.0 \mathrm{~Hz}), 7.18(1 \mathrm{H}, \mathrm{d}, J=$ $0.8 \mathrm{~Hz}), 7.26-7.34(3 \mathrm{H}, \mathrm{m}), 7.52-7.56(2 \mathrm{H}, \mathrm{m}), 7.61(1 \mathrm{H}, \mathrm{t}, J=4.8 \mathrm{~Hz})$, $8.98(2 \mathrm{H}, \mathrm{d}, J=4.8 \mathrm{~Hz})$. FAB-MS $m / z: 506\left(\mathrm{M}^{+}+1\right)$. HR-MS Calcd for $\mathrm{C}_{25} \mathrm{H}_{24} \mathrm{~N}_{5} \mathrm{O}_{5} \mathrm{~S} m / z 506.1498\left(\mathrm{M}^{+}+1\right)$, Found 506.1484.

(E)-N-[6-Methoxy-5-(2-methoxyphenoxy)-2-(pyrimidin-2-yl)pyrimidin4-yl]-1-methyl-2-(2,4,6-trimethylphenyl)ethenesulfonamide (6x) (Method F): $169 \mathrm{mg}$ (43\%): mp 190-192 ${ }^{\circ} \mathrm{C}$ (MeOH-EtOH). $400 \mathrm{MHz}{ }^{1} \mathrm{H}-\mathrm{NMR}$ $\left(\right.$ DMSO- $\left.d_{6}\right) \delta: 1.77(3 \mathrm{H}, \mathrm{s}), 1.83(6 \mathrm{H}, \mathrm{s}), 2.19(3 \mathrm{H}, \mathrm{s}), 3.83(3 \mathrm{H}, \mathrm{s}), 4.03$ $(3 \mathrm{H}, \mathrm{s}), 6.65(1 \mathrm{H}, \mathrm{d}, J=7.6 \mathrm{~Hz}), 6.78-6.88(3 \mathrm{H}, \mathrm{m}), 7.05(1 \mathrm{H}, \mathrm{t}, J=7.6 \mathrm{~Hz})$, $7.11(1 \mathrm{H}, \mathrm{d}, J=7.6 \mathrm{~Hz}), 7.56(1 \mathrm{H}, \mathrm{t}, J=4.8 \mathrm{~Hz}), 7.71(1 \mathrm{H}, \mathrm{s}), 8.88(2 \mathrm{H}, \mathrm{d}$, $J=4.8 \mathrm{~Hz}), 11.28(1 \mathrm{H}, \mathrm{s})$. FAB-MS $m / z: 546\left(\mathrm{M}^{+}-1\right)$. Anal. Calcd for $\mathrm{C}_{28} \mathrm{H}_{29} \mathrm{~N}_{5} \mathrm{O}_{5} \mathrm{~S}$ : C, 61.41; H, 5.34; N, 12.79; S, 5.86. Found: C, 61.27; H, $5.32 ; \mathrm{N}, 12.93 ; \mathrm{S}, 5.86$.

$(E)-4-(2-\{N$-[6-Methoxy-5-(2-methoxyphenoxy)-2-(pyrimidin-2-yl)pyrimidin-4-yl]sulfamoyl ethenyl)benzoic Acid (61) Sodium (170 mg, $7.39 \mathrm{mmol})$ was added to methanol $(10 \mathrm{ml})$ and stirred at room temperature until all sodium was dissolved. Methyl $(E)-4-(2-\{N-[6-$ chloro-5-(2-methoxyphenoxy)-2-(2-pyrimidinyl)-4-pyrimidinyl] sulfamoyl $\}$ ethenyl)benzoate $(\mathbf{5 k})$ $(410 \mathrm{mg}, 0.740 \mathrm{mmol})$ was added to the solution, and the mixture was stirred at $50^{\circ} \mathrm{C}$ for $4 \mathrm{~h}$. The mixture was concentrated in vacuo. $1 \mathrm{~m}$ aqueous $\mathrm{HCl}$ was added to the residue, and the resulting precipitate was collected by filtration. The solid was washed with EtOH to give 61 ( $350 \mathrm{mg} 88 \%)$ as a yellow solid: $\mathrm{mp}>250{ }^{\circ} \mathrm{C}$ (EtOH). $400 \mathrm{MHz}{ }^{1} \mathrm{H}-\mathrm{NMR}$ (DMSO- $d_{6}$ ) $\delta: 3.83$ $(3 \mathrm{H}, \mathrm{s}), 3.90(3 \mathrm{H}, \mathrm{s}), 6.67(1 \mathrm{H}, \mathrm{d}, J=8.4 \mathrm{~Hz}), 6.82(1 \mathrm{H}, \mathrm{t}, J=7.2 \mathrm{~Hz}), 7.03$ $(1 \mathrm{H}, \mathrm{t}, J=7.6 \mathrm{~Hz}), 7.09(1 \mathrm{H}, \mathrm{d}, J=7.6 \mathrm{~Hz}), 7.65-7.74(1 \mathrm{H}, \mathrm{m}), 7.82-7.92$ $(3 \mathrm{H}, \mathrm{m}), 8.00(2 \mathrm{H}, \mathrm{d}, J=8.0 \mathrm{~Hz}), 8.11(1 \mathrm{H}, \mathrm{d}, J=15.6 \mathrm{~Hz}), 9.10(2 \mathrm{H}, \mathrm{d}$, $J=4.4 \mathrm{~Hz}), 11.59(1 \mathrm{H}, \mathrm{s}), 13.15(1 \mathrm{H}, \mathrm{s})$. FAB-MS $m / z: 536\left(\mathrm{M}^{+}+1\right)$. Anal. Calcd for $\mathrm{C}_{25} \mathrm{H}_{21} \mathrm{~N}_{5} \mathrm{O}_{7} \mathrm{~S}: \mathrm{C}, 56.07 ; \mathrm{H}, 3.95 ; \mathrm{N}, 13.08 ; \mathrm{S}, 5.99$. Found: $\mathrm{C}$, $55.83 ; \mathrm{H}, 3.80 ; \mathrm{N}, 13.18 ; \mathrm{S}, 6.01$.

Methyl $(E)-4-(2-\{N$-[6-methoxy-5-(2-methoxyphenoxy)-2-(pyrimidin2-yl)pyrimidin-4-yl]sulfamoyl ethenyl)benzoate (6k) To the solution of $6 \mathbf{l}(150 \mathrm{mg}, 0.280 \mathrm{mmol})$ in $\mathrm{MeOH}(10 \mathrm{ml})$ was added concentrated sulfuric acid $(0.1 \mathrm{ml}, 1.88 \mathrm{mmol})$ and the solution was heated under reflux for $18 \mathrm{~h}$. The mixture was concentrated in vacuo, and water was added to the residue. It was extracted with $\mathrm{CHCl}_{3}$. The organic layer was washed with brine and concentrated in vacuo. The residual solid was recrystallized from EtOAc to give $6 \mathbf{k}(102 \mathrm{mg}, 66 \%)$ as colorless crystals: $\mathrm{mp} 178-179^{\circ} \mathrm{C} .400 \mathrm{MHz}{ }^{1} \mathrm{H}-$ NMR (DMSO- $\left.d_{6}\right) \delta: 3.83(3 \mathrm{H}, \mathrm{s}), 3.87(3 \mathrm{H}, \mathrm{s}), 3.89(3 \mathrm{H}, \mathrm{s}), 6.67(1 \mathrm{H}, \mathrm{d}$, $J=7.6 \mathrm{~Hz}), 6.75-6.85(1 \mathrm{H}, \mathrm{m}), 6.96-7.06(1 \mathrm{H}, \mathrm{m}), 7.09(1 \mathrm{H}, \mathrm{d}, J=$ $7.6 \mathrm{~Hz}), 7.66-7.74(1 \mathrm{H}, \mathrm{m}), 7.80-7.95(3 \mathrm{H}, \mathrm{m}), 8.03(2 \mathrm{H}, \mathrm{d}, J=7.6 \mathrm{~Hz})$, $8.13(1 \mathrm{H}, \mathrm{d}, J=15.2 \mathrm{~Hz}), 9.09(2 \mathrm{H}, \mathrm{d}, J=4.8 \mathrm{~Hz}), 11.60(1 \mathrm{H}, \mathrm{s}, \mathrm{Hz})$. FABMS $m / z$ : $550\left(\mathrm{M}^{+}+1\right)$. Anal. Calcd for $\mathrm{C}_{26} \mathrm{H}_{23} \mathrm{~N}_{5} \mathrm{O}_{7} \mathrm{~S}: \mathrm{C}, 56.82 ; \mathrm{H}, 4.22 ; \mathrm{N}$, 12.74; S, 5.83. Found: C, 56.51; H, 4.21; N, 12.56; S, 5.71.

Binding Assay For competition studies, ${ }^{125}$ I]ET-1 (200 pM) was added to each membrane preparation, which was incubated with various concentrations of compounds in $250 \mu \mathrm{l}$ of assay buffer containing $50 \mathrm{~mm}$ Tris- $\mathrm{HCl}$, $\mathrm{pH} 7.4,10 \mathrm{~mm} \mathrm{MgCl}_{2}$ and $0.01 \%$ Bovine Serum Albumin (BSA). Binding reactions were initiated by the addition of the membrane preparations. After the incubation period ( $180 \mathrm{~min}$, room temperature), the reaction was terminated by the addition of $3 \mathrm{ml}$ of ice-cold Tris buffer ( $50 \mathrm{~mm}$ Tris- $\mathrm{HCl}, \mathrm{pH}$ 7.4, $10 \mathrm{~mm} \mathrm{MgCl}_{2}$ and $0.01 \%$ BSA) followed by rapid filtration through Whatman GF/C filters. The filters were rinsed twice and the radioactivity retained on the filters was counted using a gamma counter at $60 \%$ efficiency. Each assay was performed in duplicate and nonspecific binding was assessed in the presence of $100 \mathrm{~nm}$ unlabeled ET-1. The $\mathrm{IC}_{50}$ values were calculated with a non-linear regression analysis.

Functional Assay in Vivo (Inhibition of Pressor Response to Big ET1): Conscious Normotensive Rats Male Wistar rats were anesthetized with sodium pentobarbital $(60 \mathrm{mg} / \mathrm{kg}$ i.p.). The right common carotid artery and the left jugular vein were cannulated with a polyethylene tube for determination of blood pressure and heart rate, and for i.v. administration of big ET-1 $(0.5 \mathrm{nmol} / \mathrm{kg})$. The animals were allowed to recover for 2 to $3 \mathrm{~d}$ after the operation, during which time they were housed in individual cages with free access to rat chow and water. After an appropriate equilibration period, bolus i.v. doses of big ET-1 were administered to determine control responses and patency of catheters. Each rat was treated with a single p.o. dose of antagonist or vehicle ( $0.5 \%$ methyl cellulose) and any changes in blood pressure were noted. The percentage of the pressor responses to big ET-1 challenges during the subsequent $6.5 \mathrm{~h}$ and at $24 \mathrm{~h}$ were used as a measure of big ET-1 inhibition. 
Functional Assay in Vivo (Inhibition of Pressor Response to Big ET1): Pithed Rats In vivo antagonistic activity in pithed rats was evaluated according to the method of Clozel et al. described previously. $\left.{ }^{7 g}\right)$ Briefly, male Wistar rats were pithed under sodium pentobarbital anesthesia and artificially ventilated with room air. The right common carotid artery and the left femoral vein were cannulated for blood pressure measurements and i.v. injection of drugs, respectively. After stabilization of blood pressure, various doses of $(1 \mathrm{ml} / \mathrm{kg})$ test compounds or vehicle (distilled water) were injected. Five minutes later, the first dose of big ET-1 was injected intravenously. In another series of experiments, the oral activities of test compounds were assessed. Varying doses of $(5 \mathrm{ml} / \mathrm{kg})$ test compounds or vehicle $(0.5 \%$ methyl cellulose) were administered by gastric gavage with a cannula. About $20 \mathrm{~min}$ later, the rats were anesthetized with sodium pentobarbital, and $30 \mathrm{~min}$ later, pithed and ventilated. After stabilization of blood pressure, the first dose of big ET-1 was injected intravenously. In this study, the $\mathrm{DR}_{2}$ value was defined as the dose of test compounds which was required to produce a 2-fold rightward shift of the dose-response curves of big ET-1 in DBP.

Acknowledgments We are grateful to Dr. Toshio Okazaki and Dr. Shuichi Sakamoto for their advice. We thank Mr. Masanao Sanagi and Miss Akiko Koakutsu for the pharmacological study. We also thank members of the Division of Analytical Research for performing instrumental analyses.

\section{References and Notes}

1) Present address: Bulk Manufacturing \& Technology Division, Yamanouchi Pharmaceutical Co.,Ltd., 160-2 Matsukubo, Akahama, Takahagi, Ibaraki 318-0001, Japan.

2) Present address: Corporate Planning Department, Yamanouchi Pharmaceutical Co., Nihonbashi Honcho, Chuo-ku, Tokyo 103-0023, Japan.

3) Yanagisawa M., Kurihara H., Kimura S., Tomobe Y., Kobayashi M., Mitsui Y., Goto K., Masaki T., Nature (London), 332, 411-415 (1988).

4) Inoue A., Yanagisawa M., Kimura S., Kasuya Y., Miyauchi T., Goto K., Masaki T., Proc. Natl. Acad. Sci. U.S.A., 86, 2863-2867 (1989).

5) a) Rubanyi G. M., Polokoff M. A., Pharmacol. Rev., 46, 325-415 (1994); b) Warner T., Cardiovasc. Drug Rev., 12, 105-122 (1994); c) Benigni A., Remuzzi G., Lancet, 353, 133-138 (1999).

6) a) Arai H., Hori S., Aramori I., Ohkubo H., Nakanishi S., Nature (London), 348, 730-732 (1990); b) Sakurai T., Yanagisawa M., Takuwa Y., Miyazaki H., Kimura S., Goto K., Masaki T., ibid., 348, 732-735 (1990).

7) a) Stein P. D., Floyd D. M., Bisaha S., Dickey J., Girotra R. N.,
Gougoutas J. Z., Kozlowski M., Lee V. G., Liu E. C.-K., Malley M. F., McMullen D., Mitchell C., Moreland S., Murugesan N., Serafino R., Webb M. L., Zhang R., Hunt J. T., J. Med. Chem., 38, 1344-1354 (1995); b) Doherty A. M., Patt W. C., Edmunds J. J., Berryman K. A., Reisdorph B. S., Plummer M. S., Shahripour A., Lee C., Cheng X.-M., Walker D. M., Haleen S. J., Keiser J. A., Welch K. M., Hallak H., Taylor D. G., Reynolds E. E., ibid., 38, 1259-1263 (1995); c) Roux S., Breu V., Giller T., Neidhart W., Ramuz H., Coassolo P., Clozel J. P., Clozel M., J. Pharmacol. Exp. Ther., 283, 1110-1118 (1997); d) Wu C., Chan M. F., Stavros F., Raju B., Okun I., Mong S., Keller K. M., Brock T., Kogan T. P., Dixon R. A. F., J. Med. Chem., 40, 1690-1697 (1997); e) Winn M., von Geldern T. W., Opgenorth T. J., Jae H.-S., Tasker A. S., Boyd S. A., Kester J. A., Mantei R. A., Bal R., Sorensen B. K., Wu-Wong J. R., Chiou W. J., Dixon D. B., Novosad E. I., Hernandes L., Marsh K. C., ibid., 39, 1039-1048 (1996); $f$ ) Riechers H., Albrecht H.-P., Amberg W., Baumann E., Bernard H., Bohm H.-J., Klinge D., Kling A., Muller S., Raschak M., Unger L., Walker N., Wernet W., ibid., 39, 2123-2128 (1996); g) Clozel M., Breu V., Gray G. A., Kalina B., Loffler B. M., Burri K., Cassal J. M., Hirth G., Muuler M., Neidhart W., Ramuz H., J. Pharmacol. Exp. Ther., 270, 228 -235 (1994); h) Elliott J. D., Lago M. A., Cousins R. D., Gao A., Leber J. D., Erhard K. F., Nambi P., Elshourbagy N. A., Kumar C., Lee J. A., Bean J. W., DeBrosse C. W., Eggleston D. S., Brooks D. P., Fueurstein G., Ruffolo R. R., Weinstock J., Gleason J. G., Peishoff C. E., Ohlstein E. H., J. Med. Chem., 37, 1553-1557 (1994).

8) a) Harada H., Kazami J., Watanuki S., Tsuzuki R., Sudoh K., Fujimori A., Tsukamoto S., Tanaka., Yanagisawa I., Chem. Pharm. Bull., 49, 606-612 (2001); b) Harada H., Kazami J., Watanuki S., Tsuzuki R., Sudoh K., Fujimori A., Sanagi M., Orita M., Shimaya J., Nakahara H., Tsukamoto S., Tanaka., Yanagisawa I., Bioorg. \& Med. Chem., 9, 2955-2968 (2001).

9) Neidhart W., Breu V., Bur D., Burri K., Clozel M., Hirth G., Müller M., Wessel H. P., Ramuz H., Chimia, 20, 519-524 (1996).

10) Hirooka S., Tanbo Y., Takemura K., Makahashi H., Matsuoka T., Kuroda S., Bull. Chem. Soc. Jpn., 64, 1431-1433 (1991).

11) Culbertson B. M., Dietz S., J. Chem. Soc. (C), 1968, 992-993.

12) Wasylishen R., Schafer T., Can. J. Chem., 50, 2710-2712 (1072); Idem, ibid., 51, 961—973 (1973).

13) Matsuura T., Yukimura T., Kim S., Miura K., Iwao H., Jpn. J. Pharmacol., 71, 213-222 (1996).

14) Hasegawa K., Hirooka S., Kawahara H., Tanaka A., Nomura M., Hori Y., Bull. Chem. Soc. Jpn., 50, 2346-2350 (1977). 